\title{
Does Antarctic glaciation cool the world?
}

\author{
A. Goldner ${ }^{1}$, M. Huber ${ }^{1,3}$, and R. Caballero ${ }^{2}$ \\ ${ }^{1}$ Earth, Atmospheric, and Planetary Sciences, Purdue University, West Lafayette, Indiana, USA \\ ${ }^{2}$ Department of Meteorology (MISU) and Bert Bolin Center for Climate Research, Stockholm University, Stockholm, Sweden \\ ${ }^{3}$ Purdue Climate Change Research Center, Purdue University, West Lafayette, Indiana, USA
}

Correspondence to: A. Goldner (agoldner@purdue.edu)

Received: 19 June 2012 - Published in Clim. Past Discuss.: 18 July 2012

Revised: 2 January 2013 - Accepted: 14 January 2013 - Published: 24 January 2013

\begin{abstract}
In this study, we compare the simulated climatic impact of adding an Antarctic ice sheet (AIS) to the "greenhouse world" of the Eocene and removing the AIS from the modern world. The modern global mean surface temperature anomaly $(\Delta T)$ induced by Antarctic Glaciation depends on the background $\mathrm{CO}_{2}$ levels and ranges from -1.22 to $-0.18 \mathrm{~K}$. The Eocene $\Delta T$ is nearly constant at $\sim-0.25 \mathrm{~K}$. We calculate an climate sensitivity parameter $S_{\text {[Antarctica] }}$ which we define as $\Delta T$ divided by the change in effective radiative forcing ( $\left.\Delta Q_{\text {Antarctica }}\right)$ which includes some fast feedbacks imposed by prescribing the glacial properties of Antarctica.

The main difference between the modern and Eocene responses is that a negative cloud feedback warms much of the Earth's surface as a large AIS is introduced in the Eocene, whereas this cloud feedback is weakly positive and acts in combination with positive sea-ice feedbacks to enhance cooling introduced by adding an ice sheet in the modern. Because of the importance of cloud feedbacks in determining the final temperature sensitivity of the AIS, our results are likely to be model dependent. Nevertheless, these model results suggest that the effective radiative forcing and feedbacks induced by the AIS did not significantly decrease global mean surface temperature across the Eocene-Oligocene transition (EOT -34.1 to $33.6 \mathrm{Ma}$ ) and that other factors like declining atmospheric $\mathrm{CO}_{2}$ are more important for cooling across the EOT. The results illustrate that the efficacy of AIS forcing in the Eocene is not necessarily close to one and is likely to be model and state dependent. This implies that using EOT paleoclimate proxy data by itself to estimate climate sensitivity for future climate prediction requires climate models and consequently these estimates will have large uncertainty, largely due to uncertainties in modelling low clouds.
\end{abstract}

\section{AIS temperature sensitivity}

During the Eocene-Oligocene Transition (EOT) global climate deteriorated as the warm and ice-free conditions of the Eocene gave way to a colder, glaciated state in the early Oligocene (Lear et al., 2000; Zachos et al., 2001; DeConto and Pollard, 2003; Macksensen and Ehrmann, 1992; Scher et al., 2011; Hambrey and Barrett, 1993). Evidence now exists that the cooling (Liu et al., 2009; Eldrett et al., 2009; Zanazzi et al., 2007; Ivany et al., 2000) and glaciation (Lear et al., 2000; Edgar et al., 2007; Coxall et al., 2005; Miller et al., 2009; DeConto and Pollard, 2003; Zachos et al., 2001) that occurred across the EOT was caused by a drop in $\mathrm{CO}_{2}$ mixing ratios from $\sim 1000$ to $\sim 600 \mathrm{ppm}$ (Pagani et al., 2011; Pearson et al., 2009). These values are in the likely range of values over the next century. The modern Earth system is currently in a glaciated state, but is showing signs of potentially losing glacier ice in the Arctic and Antarctic in the future (Joughin and Alley, 2011; Jacob et al., 2012; Velicogna, 2009; Chen et al., 2009; Pritchard et al., 2009; Liston and Hiemstra, 2011). Thus a major, unanswered question in future climate change prediction is the degree to which melting of ice sheets in the future will contribute to substantially and irreversibly altering climate (Solomon et al., 2009). Past climate changes, such as the EOT may provide unique information to answer that question, but serious challenges remain.

Indeed, with both greenhouse gas forcing and temperature change values in hand from EOT proxy records there is a temptation to estimate an Earth system sensitivity (ESS) parameter (Lunt et al., 2010), i.e., a climate sensitivity parameter that includes the direct, fast feedback responses to radiative perturbation combined with the slower feedbacks, such as ice sheet growth, greenhouse gas and vegetation feedbacks (Paleosens members, 2012; Royer et al., 2012). One 
approach is to use this Eocene ESS to draw a straightforward analogy to the future (Hansen et al., 1984, 2010; Hansen and Sato, 2012; Kiehl, 2011; Hay, 2011) avoiding the problems of accurately reproducing the individual processes and feedbacks which hamper modelling efforts (Roe and Baker, 2007).

We are motivated in this paper by the following concerns. On long time scales does a glaciated Antarctica cool global mean temperature? Does the Antarctic ice sheet (AIS) induce additional positive or negative climate feedbacks and if so what are the strength of these feedbacks? Are the results of this change dependent on background state?

Recent estimates indicate that $\mathrm{CO}_{2}$ levels over the EOT fell from 1000 to 600 ppm (Pearson et al., 2009; Pagani et al., 2011, Myhre et al., 1998), causing a $\sim 2.1-2.5 \mathrm{~W} \mathrm{~m}^{-2}$ radiative forcing. To reconcile this forcing with the temperature shift at the EOT of $\sim 3.5 \pm 1.5 \mathrm{~K}$ (Liu et al., 2009) assuming that this shift was entirely due to the fast feedbacks - would require a Charney-type temperature sensitivity of $\sim 1.5 \mathrm{~K}\left(\mathrm{~W} \mathrm{~m}^{-2}\right)^{-1}$. By comparison a typical estimated modern value is $0.8 \mathrm{~K}\left(\mathrm{~W} \mathrm{~m}^{-2}\right)^{-1}$ (Bitz et al., 2012; Kay et al., 2012a; Gettelman et al., 2012).

Thus while the shift in $\mathrm{CO}_{2}$ values over the EOT is more or less well established as the prime candidate for driving the cooling, this implies either a large value of fast sensitivity or substantial slow Earth system positive feedback that enhances the sensitivity. It is currently unknown, and indeed impossible to know directly from proxy data, what fraction of the cooling at the EOT was a direct climate response involving the fast, Charney-type feedbacks, such as shifts in clouds and sea ice (Hansen et al., 1981, 1997; DeConto et al., 2007) and what fraction of the cooling involved the slower feedbacks, such as changes in the AIS (Lunt et al., 2010), given that proxy records for the radiative forcing due to ice sheets do not exist. Here we will show, that adding or removing an ice sheet can have impacts that are strongly state dependent and are likely to be model dependent as well. This is a less straightforward problem than determining the forcing due to a doubling of $\mathrm{CO}_{2}$.

We are focused in this paper on understanding what slow, Earth system feedbacks were operating across the EOT and their interactions with fast feedbacks, to help evaluate whether these feedbacks operate in the same way (in the model) as they do in the modern (Haywood et al., 2011). Specifically, we use the National Center for Atmospheric Research (NCAR) Community Earth System Model (CESM1.0) in slab ocean mode to investigate the impact of replacing the AIS with vegetation for the future case, and replacing vegetation with an ice sheet for the EOT cases. We ask the following questions: what is the climatic impact of adding or removing a large AIS? Does this response depend on the climate state, in particular is the response in the Eocene different than in the modern? What feedbacks are important for modulating this response?
The remainder of paper will be focused on explaining and quantifying temperature change, effective radiative forcing, and the resulting climate sensitivity parameter induced by removing and adding the AIS and comparing this response in Eocene and modern contexts. This paper is broken into four sections. Section 2 describes the CESM1.0 modelling framework and how we constructed our Eocene and modern glaciated and unglaciated simulations. Then we present the climate sensitivity to Antarctic glaciation in modern and Eocene slab ocean simulations (Sect. 3.1) and describe the atmospheric response to Antarctic glaciation in the Eocene and modern slab ocean simulations (Sect. 3.2). Sections 4 and 5 include the discussion and conclusion, respectively.

\section{Methods}

\subsection{CESM1.0 modelling framework}

We perform a series of slab ocean global climate model simulations using the NCAR CESM1.0 as described in Neale et al. (2010), Gent et al. (2011), and Bitz et al. (2012). The CESM1.0 configuration includes the Community Atmosphere Model (CAM4), the Community Land Model (CLM4) (Lawrence et al., 2012), and the Community Sea-Ice Model (CICE4) (Hunke and Lipscomb, 2008; Brady et al., 2012) coupled to a slab ocean.

CAM4 employs the revised Zhang and McFarlane parameterized deep convection scheme and finite volume dynamical core (Lin, 2004; Gent et al., 2011; Mishra et al., 2011; Zhang and McFarlane, 1995). We use the $2^{\circ} \times 2.5^{\circ}$ finite volume core because it is able to adequately resolve the finer scales important for atmospheric hydrology and energy conservation and this configuration has a reduced numerical dispersion in comparison to the CAM3 spectral core (Neale et al., 2010), which we have used for past paleoclimate applications (Huber and Caballero, 2011). CAM4 has an improved calculation of freeze-drying which reduces biases in the low cloud properties and the radiative budget in the high latitudes compared to CAM3 (Neale et al., 2012; Vavrus and Waliser, 2008). These improvements lead to improved high latitude temperature seasonality in modern simulations between CAM3 and CAM4 (Bitz et al., 2012). When CAM4 cloud distributions are compared against the international satellite cloud climatology project (ISCCP) and CALIPSO data, the model is able to spatially match cloud observations in the tropics and extra-tropics (Kay et al., 2012b), but CAM4 underrepresents the total cloud fraction in the Arctic region (Boer et al., 2012).

Until recently, deep time paleoclimate simulations with CAM have used prescribed aerosol datasets based on preindustrial values or have set the global aerosol optical depth to a coefficient specified value. Here, we create prescribed aerosol forcing files specifically for the late Eocene. Building these files requires a two step process. First, we run 
CAM4.0 in bulk aerosol mode (BAM) (Lamarque et al., 2012; Tie et al., 2005) with late Eocene boundary conditions. The paleoclimate configuration of aerosol files in CAM4 BAM is explained in detail in Heavens et al. (2012). The CAM4 BAM configuration allows for the aerosol variables like sea salt, dust, $\mathrm{SO}_{4}, \mathrm{SO}_{2}$, to be solved prognostically (Seland et al., 2008; Kirkeva et al., 2008) within a late Eocene climate simulation. The equilibrated CAM4 BAM model output is then used to create prescribed aerosol forcing files for input CAM4 Eocene simulations. The prescribed aerosol files should improve the realism and self consistency of the prescribed aerosol forcing in the Eocene simulations because aerosol concentrations and spatial coverage are derived from Eocene boundary conditions. Initial comparison between Eocene simulations using the PI prescribed aerosol forcing file compared to the Eocene derived CAM4 BAM aerosols results in a negligible global mean temperature response in CAM4 Eocene simulations and it should be noted that CAM4 does not include cloud indirect effects (Gent et al., 2011) meaning that changing aerosol concentrations will not have an effect on cloud fractions or lifetime. Another improvement of CESM1.0 over prior modelling efforts is that the ice model (CICE4) includes a new scattering parameterization scheme (Briegleb and Light, 2007) which should increase the realism of snow albedo and short-wave forcing effects (Gent et al., 2011).

The CESM1.0 slab configuration has fully dynamic interactive sea ice unlike the previous version of CCSM3.0 which had purely thermodynamic sea ice (Kay et al., 2011, 2012a). The slab configuration incorporates heat convergence, mixed layer depths, and salinity from existing NCAR Community Climate Model version 3 (CCSM3.0) fully coupled simulations. A series of previous CCSM3.0 fully coupled Eocene simulations were used to create the slab ocean datasets and ocean slab fluxes. These CCSM3 simulations were integrated over 3000 model years and run at 560, 1120, $2240 \mathrm{ppm} \mathrm{CO}_{2}$. Details can be found in Liu et al. (2009), Ali and Huber (2010), Huber and Caballero (2011), and Huber and Goldner (2011). The final $40 \mathrm{yr}$ of ocean heat convergence, salinity, temperature, and ocean currents from the fully coupled Eocene simulations are used as climatologies to create the CESM1.0 slab ocean forcing file. In a series of simulations from Eocene through Miocene and using a variety of models, we have shown that ocean heat transport is relatively stable (Huber and Sloan, 2001; Huber et al., 2004; Sijp et al., 2011; Herold et al., 2012) and not the first order control on Antarctic surface conditions (Huber and Nof, 2006). Additionally, preliminary CESM1.0, fully coupled simulations show that there are no appreciable ocean circulation differences between the models so we are confident that utilizing CCSM3 ocean fields is not a concern. The slab ocean configuration allows us to run many sensitivity studies to equilibrium and our simulations are run for $60 \mathrm{yr}$ with the last $20 \mathrm{yr}$ used for analysis. In this paper will present only a small subset

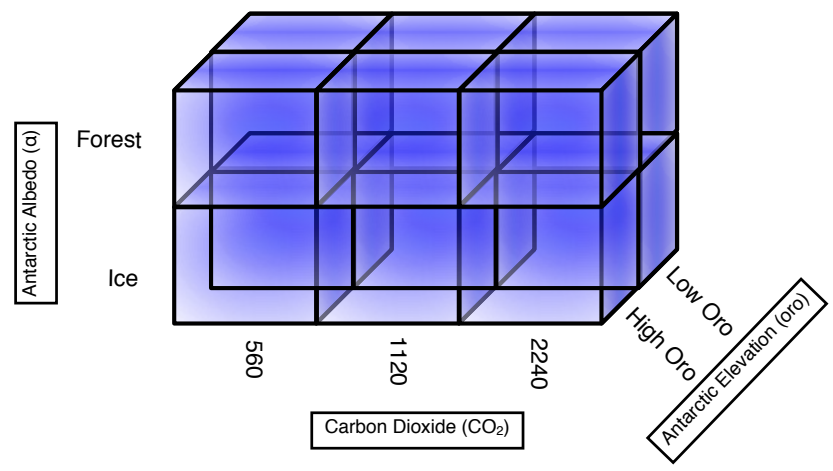

Fig. 1. Schematic describing the suite of modern and Eocene Antarctic glacier simulations that were completed in this study. Along the $\mathrm{x}$-axis we plot the levels of $\mathrm{CO}_{2}$, along the $\mathrm{y}$-axis we plot the changes in albedo $(\alpha)$ over Antarctica, and along the z-axis we plot the topographical changes (oro) over Antarctica.

of sensitivity studies conducted, and the results focus on the main features revealed from all simulations.

To set the stage for describing the methodology for the glacier simulations, we present Fig. 1, which is a schematic of the simulations that were completed to explore the climate impacts to changes in the AIS. Because shifts in the Antarctic ice sheet include topographical changes and albedo changes, we show the possible simulations using a three dimensional schematic (Fig. 1).

\subsection{Antarctic sensitivity study methods}

To investigate the modern Antarctic glacier sensitivity, we take the default modern Antarctica topography dataset (Fig. 2a) and decrease its height uniformly by $80 \%$. This lowers the Antarctic topography to $500-1000 \mathrm{~m}$ (Fig. 2b) and is a gross estimation for what the unglaciated modern world would look like without the modern Antarctic height and albedo and after allowing for glaciostatic rebound. Our goal here is not on projecting future Antarctic topography with exact verisimilitude, but producing something approximately correct and comparable to our Eocene conditions.

The unglaciated low topography used in the Eocene simulation (Sewall et al., 2000) is plotted in Fig. 2c. To create the glaciated Eocene simulations, we introduce a large modern ice sheet over the Antarctic continent, increasing the mean height to 3000-4000 m (Fig. 2d). More advanced approaches, for example using the new ANTSCAPE Antarctic paleotopography (Wilson et al., 2011) or using ice sheet topographies from DeConto et al. (2007), would enhance the realism of our study but at the expense of adding complexity. We prefer simplicity for this set of experiments. Preliminary results with more realistic Antarctic topographies indicate that our main results are not changed by this simplification.

In conjunction with changes in glacial topography, we remove the effect of ice albedo by replacing the land 

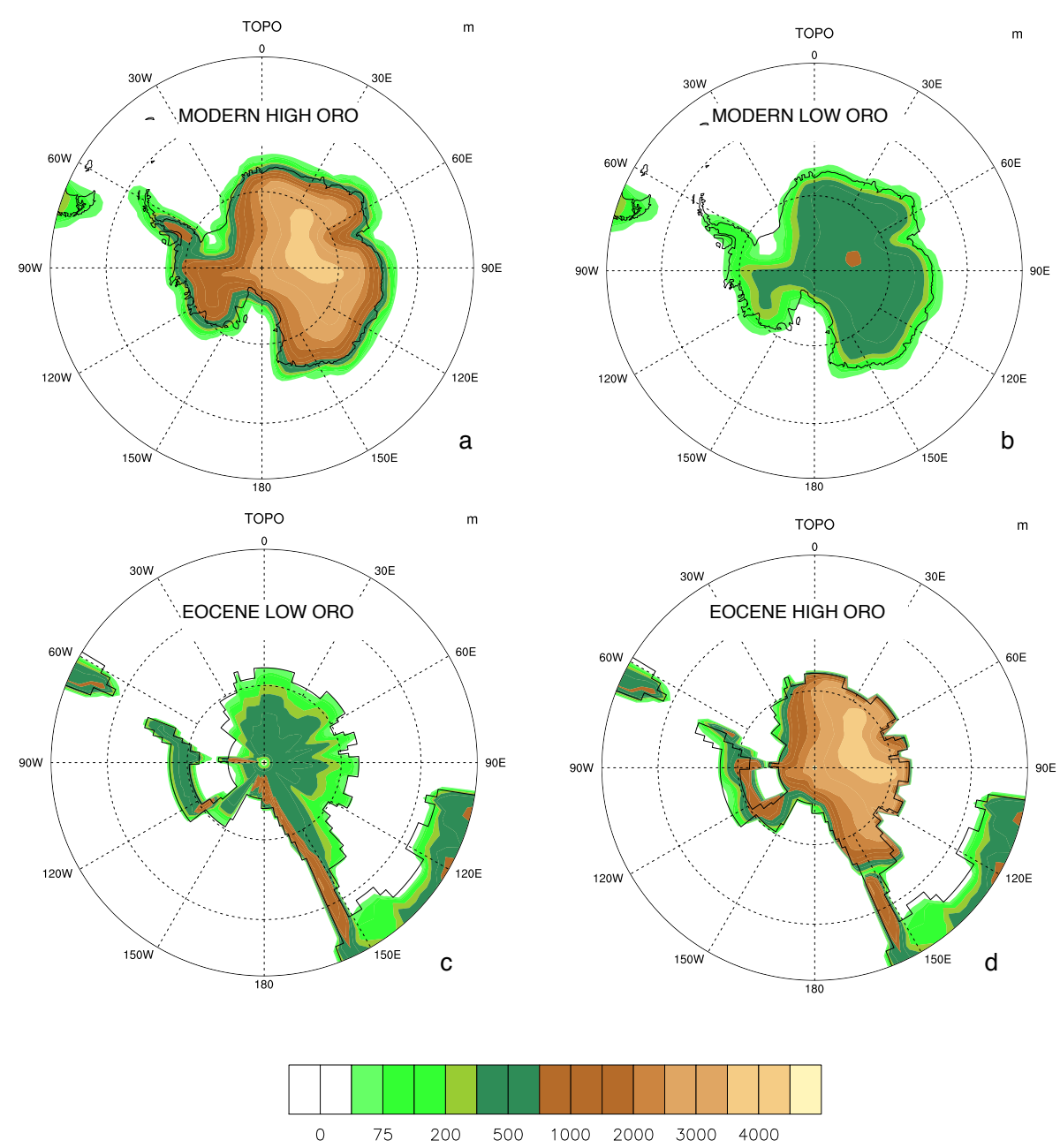

Fig. 2. (a) Antarctic topography in the modern glaciated high topography simulations (m). (b) Antarctic topography used in the unglaciated modern low topography simulations. (c) Antarctic topography in the unglaciated Eocene simulation. (d) Antarctic topography in the Eocene glaciated simulation based on the modern-day Antarctic height. Oro sensitivity experiments in the text refer to changing these topographies.

surface type with broadleaf boreal forest. The surface albedo anomaly between the glaciated and unglaciated simulation after fast feedbacks (snow, clouds, water vapor, and sea ice) have operated is shown in Fig. 3 at 2240 ppm $\mathrm{CO}_{2}$. In Fig. 3, there is roughly a $60 \%$ drop in albedo locally in Antarctica when the topography is lowered and replaced with broadleaf boreal forest during the austral summer (December, January, February). We run the glaciated versus unglaciated simulations at the same $\mathrm{CO}_{2}$ levels but test Antarctic sensitivity to $\mathrm{CO}_{2}$ by varying $\mathrm{CO}_{2}$ levels over a wide range $(560,1120$, and $2240 \mathrm{ppm}$ ).

In summary, the height of Antarctica is identical in the glaciated Eocene and modern simulations, but the area of Antarctica in the Eocene is roughly $30 \%$ smaller than modern following the reconstruction of Sewall et al. (2000). Because the Eocene AIS landmask is smaller than modern, we area weight the effective forcing calculation for the ice sheet and we acknowledge that this difference in landmask size could introduce a level of uncertainty into the effective forcing and temperature response between the configurations. Numerous research groups have attempted to estimate Antarctic ice volume growth at the EOT (Miller et al., 1987, 2009; Edgar et al., 2007; Bohaty et al., 2012; Coxall et al., 2005; Lear et al., 2000; Katz et al., 2008; Pusz et al., 2011; DeConto et al., 2008; Liu et al., 2009). Estimates for Antarctic glacial extent during the EOT is still uncertain so our approach is simply one of many possible approaches and this work should be considered as an exploratory sensitivity study. One process that has been largely over looked in prior work is that changing ice sheet elevation alters depth of the atmospheric column and thus it impacts the columnintegrated atmospheric absorption even under clear sky conditions. This must be accounted for in forcing calculations and this is detailed below. 

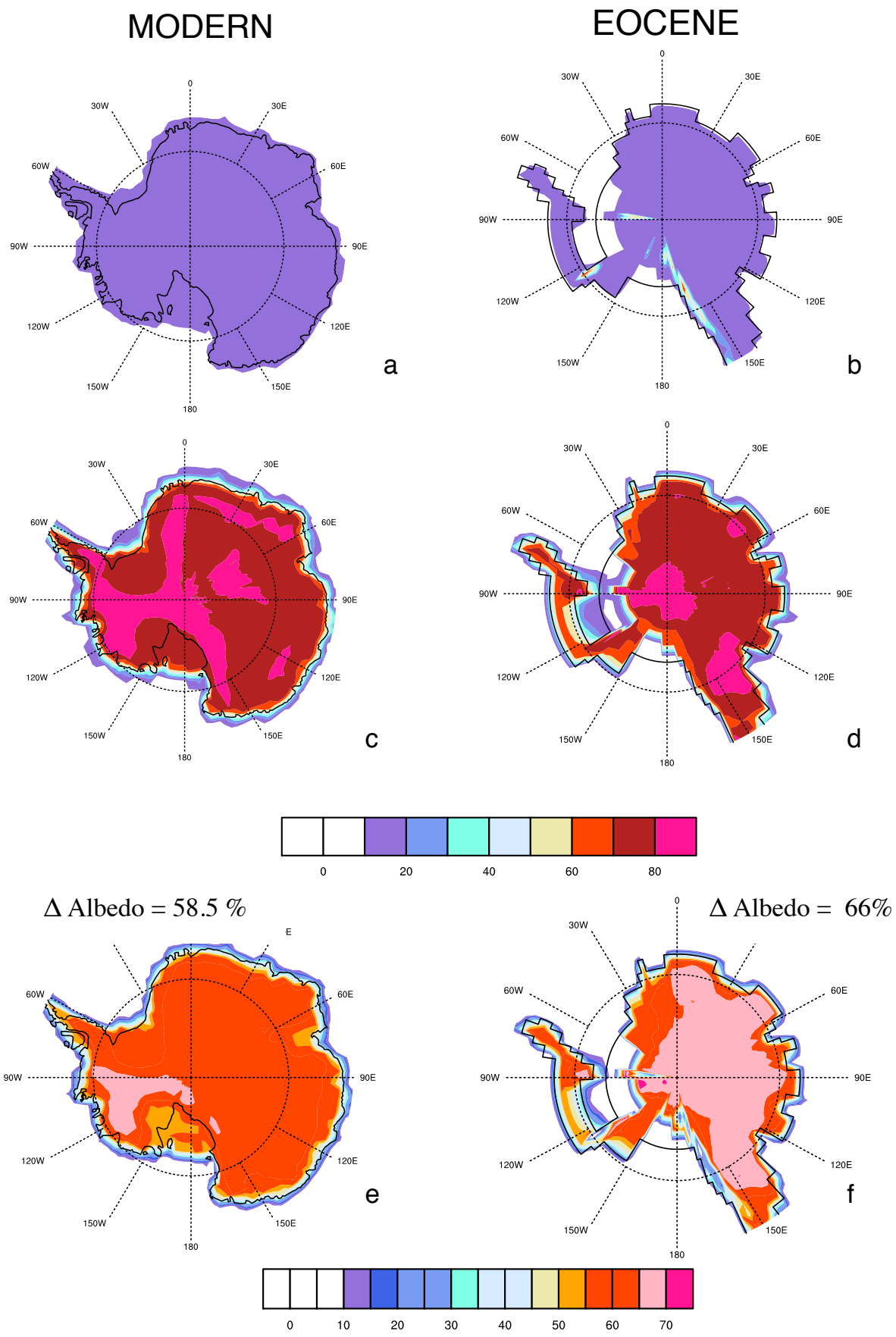

Fig. 3. Surface albedos $(\%)$ for modern and Eocene glaciated $(\alpha+$ oro) and unglaciated simulations averaged over the austral summer at $2240 \mathrm{ppm} \mathrm{CO}_{2}$. (a) Modern unglaciated simulation, (b) Eocene unglaciated simulation, (c) modern glaciated simulation, (d) Eocene glaciated simulation, (e) modern glaciated versus unglaciated, and (f) Eocene glaciated versus unglaciated.

\subsection{Radiation diagnostics and climate sensitivity parameter calculations}

In steady state we expect that changes in TOA long wave between cases must be equal to TOA short-wave changes. To verify that the simulations presented below are in steady state equilibrium, we calculate the global mean change in net short-wave radiation at the TOA between glaciated cases $\left(\right.$ FSNT $\left._{\text {glaciated }}\right)$ and unglaciated cases $\left(\mathrm{FSNT}_{\text {unglaciated }}\right)$. These calculations include all local fast feedbacks and global feedbacks of adding and removing the AIS. The calculations are performed using the net surface short-wave flux change $(\triangle \mathrm{FSNS})$ and $(\triangle \mathrm{FSNT})$ and values are recorded in Table 1. 
Table 1. Eocene and modern glaciated minus unglaciated simulations labeled by experiment type, time interval, orography change (labelled $\mathrm{Y}(\mathrm{yes})$ and $\mathrm{N}(\mathrm{no})$ ), albedo change (labelled with $\mathrm{Y}$ and $\mathrm{N}$ ), and atmospheric $\mathrm{CO}_{2}$ in ppm. Globally weighted anomalies are given for $\Delta T$ in $(\mathrm{K}), \triangle \mathrm{SWCF}, \triangle \mathrm{LWCF}$, and total cloud forcing SWCF + LWCF in $\mathrm{W} \mathrm{m}^{-2}$. Second, the table lists $\triangle \mathrm{FSNT}$ and the globally weighted Antarctic forcings ( $\Delta Q_{\text {Antarctica }}$ ) calculated using FSNSC (adjusted effective forcing see text in section 2.3). Third, the table gives values for the surface temperature sensitivity induced by the changes in albedo, topography, and $\mathrm{CO}_{2}$, such as $\Delta T_{(\alpha)}$ : the change in surface temperature due to the albedo forcing of the AIS, and $\Delta T_{(\alpha+o r o)}$ : the temperature change due to the albedo of the ice sheet and the topography of the ice sheet. Lastly, the table calculates ESS and $S$ in $\mathrm{K}\left(\mathrm{W} \mathrm{m}^{-2}\right)^{-1}$ using the different $\Delta T$ and $\Delta Q_{\text {Antarctica }}$ values. Where $S_{\left[\mathrm{Antarctica} \mathrm{CO}_{2}\right]}$ is the sensitivity to changing $\mathrm{CO}_{2}$, Antarctic albedo, Antarctic topography and $S_{\text {[Antarctica] }}$ are the sensitivity of climate to changes in Antarctic ice sheet holding atmospheric $\mathrm{CO}_{2}$ constant. Complete descriptions of the equations are written in detail in methods Sect. 2.3 .

\begin{tabular}{|c|c|c|c|c|c|c|c|c|c|c|c|c|}
\hline $\begin{array}{l}\text { Experiment } \\
\text { comparison }\end{array}$ & $\begin{array}{l}\text { Time } \\
\text { interval }\end{array}$ & $\begin{array}{c}\text { Oro } \\
\text { change }\end{array}$ & $\begin{array}{l}\text { Albedo } \\
\text { change }\end{array}$ & $\mathrm{CO}_{2}$ & $\Delta T$ & $\triangle \mathrm{SWCF}$ & $\triangle \mathrm{LWCF}$ & $\begin{array}{r}\text { Total } \\
\text { cloud } \\
\text { forcing }\end{array}$ & $\Delta \operatorname{FSNT}_{(\alpha)}$ & $\Delta \operatorname{FSNS}_{(\alpha)}$ & $\Delta \mathrm{FSNT}_{(\alpha+\text { oro })}$ & $\Delta \mathrm{FSNS}_{(\alpha+\text { oro })}$ \\
\hline$\alpha$ & MODERN & $\mathrm{N}$ & $\mathrm{Y}$ & 1120 & -1.14 & -0.21 & -0.23 & -0.44 & -1.84 & -1.59 & - & - \\
\hline$\alpha$ & MODERN & $\mathrm{N}$ & $\mathrm{Y}$ & 560 & -0.86 & -0.26 & -0.21 & -0.47 & -1.70 & -1.64 & - & - \\
\hline$\alpha+$ oro & MODERN & $\mathrm{Y}$ & $\mathrm{Y}$ & 2240 & -1.22 & 0.52 & -0.37 & 0.39 & - & - & -1.69 & -1.43 \\
\hline$\alpha+$ oro & MODERN & $\mathrm{Y}$ & $\mathrm{Y}$ & 1120 & -0.68 & -0.31 & -0.13 & -0.43 & - & - & -1.01 & -1.16 \\
\hline$\alpha+$ oro & MODERN & $\mathrm{Y}$ & $\mathrm{Y}$ & 560 & -0.18 & -0.60 & -0.13 & -0.73 & - & - & -0.88 & -0.49 \\
\hline$\alpha+$ oro $+\mathrm{CO}_{2}$ & MODERN & Y & $\mathrm{Y}$ & $560-1120$ & -2.94 & 0.36 & 0.79 & 1.15 & - & - & - & - \\
\hline $\mathrm{CO}_{2}$ & MODERN & $\mathrm{N}$ & $\mathrm{N}$ & $2240-1120$ & 3.81 & 0.57 & -0.79 & -0.22 & - & - & - & - \\
\hline $\mathrm{CO}_{2}$ & MODERN & $\mathrm{N}$ & $\mathrm{N}$ & $1120-560$ & 3.11 & 0.24 & -0.66 & -0.42 & - & - & - & - \\
\hline$\alpha$ & EOCENE & $\mathrm{N}$ & $\mathrm{Y}$ & 1120 & -0.36 & 0.18 & -0.11 & 0.76 & -0.64 & -0.43 & - & - \\
\hline$\alpha$ & EOCENE & $\mathrm{N}$ & $\mathrm{Y}$ & 560 & -0.27 & 0.06 & -0.10 & 0.43 & -0.39 & -0.25 & - & - \\
\hline$\alpha+$ oro & EOCENE & $\mathrm{Y}$ & $\mathrm{Y}$ & 2240 & -0.21 & 1.14 & -0.10 & 1.04 & - & - & -0.30 & -0.26 \\
\hline$\alpha+$ oro & EOCENE & $\mathrm{Y}$ & $\mathrm{Y}$ & 1120 & -0.17 & 1.40 & -0.14 & 1.26 & - & - & -0.27 & -0.29 \\
\hline$\alpha+$ oro & EOCENE & Y & $\mathrm{Y}$ & 560 & -0.29 & 0.91 & -0.02 & 0.89 & - & - & -0.55 & -0.45 \\
\hline$\alpha+$ oro $+\mathrm{CO}_{2}$ & EOCENE & $\mathrm{Y}$ & $\mathrm{Y}$ & $560-1120$ & -3.74 & 1.24 & 0.73 & 1.97 & - & - & - & - \\
\hline $\mathrm{CO}_{2}$ & EOCENE & $\mathrm{N}$ & $\mathrm{N}$ & $2240-1120$ & 2.91 & 1.06 & -1.37 & -0.31 & - & - & - & - \\
\hline $\mathrm{CO}_{2}$ & EOCENE & $\mathrm{N}$ & $\mathrm{N}$ & $1120-560$ & 3.46 & -0.31 & -0.78 & -1.09 & - & - & - & - \\
\hline
\end{tabular}

\begin{tabular}{lccccc}
\hline $\begin{array}{l}\text { Experiment } \\
\text { comparison }\end{array}$ & $\Delta \mathrm{FSNT}_{\left(\alpha+\text { oro }+\mathrm{CO}_{2}\right)}$ & $\Delta \mathrm{FSNS}_{\left(\alpha+\text { oro }+\mathrm{CO}_{2}\right)}$ & $\Delta Q_{\text {Antarctica }}$ & $\Delta T_{(\alpha)}$ & $\Delta T_{(\alpha+\text { oro })}$ \\
\hline$\alpha$ & - & - & -1.44 & -1.14 & - \\
$\alpha$ & - & - & -1.04 & -0.86 & - \\
$\alpha+$ oro & - & - & -3.82 & - & -1.22 \\
$\alpha+$ oro & - & - & -0.59 & - & -0.68 \\
$\alpha+$ oro & - & - & -0.62 & - & -0.18 \\
$\alpha+$ oro $+\mathrm{CO}_{2}$ & -2.07 & -0.26 & -0.74 & - & - \\
$\mathrm{CO}$ & - & - & - & - & - \\
$\mathrm{CO}_{2}$ & - & - & - & - & - \\
$\alpha$ & - & - & -0.94 & -0.36 & - \\
$\alpha$ & - & - & -0.24 & -0.27 & - \\
$\alpha+$ oro & - & - & -1.66 & - & -0.22 \\
$\alpha+$ oro & - & - & -1.54 & - & -0.17 \\
$\alpha+$ oro & - & - & -1.21 & - & -0.29 \\
$\alpha+$ oro $+\mathrm{CO}_{2}$ & -3.02 & -0.67 & -0.78 & - & - \\
$\mathrm{CO}_{2}$ & - & - & - & - & - \\
$\mathrm{CO}_{2}$ & - & - & - & - & - \\
\hline
\end{tabular}

We calculate the globally averaged temperature change $(\Delta T)$ by comparing two cases and varying one or more parameters. In the results below, we refer to the term, $\Delta T$ Antarctica, which is $\Delta T$ over the Antarctic region of 60 to $90^{\circ} \mathrm{S}$. For cases in which the AIS has been changed, we denote $\Delta T$ with the subscript ( $\alpha$ ) for changing albedo and (oro) for height of Antarctica, so we distinguish between simulations in which only the surface properties are changed $\Delta T_{(\alpha)}$ and those in which both the height and surface properties are changed, $\Delta T_{(\alpha+\text { oro })}$. We treat each separately because this will help elucidate the importance of changing the height of the AIS versus changing the albedo of the ice sheet. Additionally, in some simulations we change $\left(\alpha\right.$, oro, and $\left.\mathrm{CO}_{2}\right)$ and these cases are defined as $\Delta T_{\left(\alpha+\text { oro }+\mathrm{CO}_{2}\right)}$.

Quantifying the effective radiative forcing of the AIS is not straightforward. Prior work estimates a ice sheet forcing as being directly related to only the change in area integrated surface albedo and the inferred change in the surface energy budget (Hansen et al., 1997; Rohling et al., 2012; Myhre and Myhre, 2003; Myhre et al., 1998), while ignoring or applying 
Table 1. Continued.

\begin{tabular}{lccc}
\hline $\begin{array}{l}\text { Experiment } \\
\text { comparison }\end{array}$ & ESS & $S_{\left[\text {Antarctica, } \mathrm{CO}_{2}\right]}$ & $S_{\text {[Antarctica] }}$ \\
\hline$\alpha$ & - & - & 0.79 \\
$\alpha$ & - & - & 0.83 \\
$\alpha+$ oro & - & - & 0.44 \\
$\alpha+$ oro & - & - & 1.15 \\
$\alpha+$ oro & - & - & 0.31 \\
$\alpha+$ oro $+\mathrm{CO}_{2}$ & 0.84 & 1.35 & - \\
$\mathrm{CO}_{2}$ & - & - & - \\
$\mathrm{CO}_{2}$ & - & - & - \\
$\alpha$ & - & - & 0.28 \\
$\alpha$ & - & - & 0.82 \\
$\alpha+$ oro & - & - & 0.13 \\
$\alpha+$ oro & - & - & 0.11 \\
$\alpha+$ oro & - & - & 0.23 \\
$\alpha+$ oro $+\mathrm{CO}_{2}$ & 1.06 & 1.08 & - \\
$\mathrm{CO}_{2}$ & - & - & - \\
$\mathrm{CO}_{2}$ & - & - & - \\
\hline
\end{tabular}

a small correction to account for all the other possible radiative and dynamical feedbacks. As mentioned above, adding the AIS in the Eocene which has large amounts of low clouds over Antarctica may induce a different radiative response compared to modern, i.e., the reference state, to use feedback terminology, is different between modern and Eocene.

We quantify the change in the net surface short-wave radiation at the surface in clear sky conditions (FSNSC), which includes no direct short-wave or long-wave cloud feedback. Because the effective forcing of the AIS is occurring over a specified region, unlike $\mathrm{CO}_{2}$, which is a globally distributed forcing, we calculate the effective AIS forcing by quantifying the change in surface clear sky short-wave fluxes over just the Antarctica landmass.

To calculate the effective forcing ( $\left.\Delta Q_{\text {Antarctica }}\right)$ we take a weighted sum of the clearsky net short-wave flux difference at the surface $\triangle$ FSNSC over the model grid cells that include the land grid cells within the Antarctic landmass area $\left(\triangle \mathrm{FSNSC}_{\text {landmass }}\right)$. This number is adjusted slightly to include a radiative adjustment because when we lower AIS topography we remove some of the atmospheric column which can absorb short-wave radiation. The adjustment is calculated as the difference in downwelling clear sky shortwave radiation which changes by $10 \%$ locally as elevation is changing in these simulations. We then area-weight this adjusted $\left(\triangle \mathrm{FSNSC}_{\text {landmass }}\right)$ by the ratio:

$\mathrm{SL}=\left(\frac{\text { forcing area }}{\text { area globe }}\right)$

which are the cells associated with the Antarctic landmass $\left(\mathrm{m}^{2}\right)$ divided by the area of globe $\left(\mathrm{m}^{2}\right)$ (Eq. 1). The globally weighted forcing over the Antarctica region is
$\Delta Q_{\text {Antarctica }}=\Delta \mathrm{FSNSC}_{\text {landmass }} \cdot \mathrm{SL} ;$

summarized in Table 1.

As an important reference point, $\Delta Q_{\mathrm{CO}_{2}}$, the change in radiative forcing due to a doubling of atmospheric carbon dioxide from 280 to $560 \mathrm{ppm}$ in CAM4.0 simulations is approximatly $3.5 \mathrm{~W} \mathrm{~m}^{-2}$ (Bitz et al., 2012; Gettelman et al., 2012) which is close to the standard value used in previous work (Myhre et al., 1998). We note that this value for $\Delta Q_{\mathrm{CO}_{2}}$ is approximate, and is model dependent (Bitz et al., 2012) and not constant at higher $\mathrm{CO}_{2}$ levels (Senior and Mitchell, 2000; Boer and Yu, 2003). Table 1 also includes the Eocene and modern glaciated versus unglaciated simulations exploring

$\mathrm{ESS}=\frac{\Delta T_{\left(\alpha+\mathrm{oro}+\mathrm{CO}_{2}\right)}}{\Delta Q_{\mathrm{CO}_{2}}}$,

and $S$ the climate sensitivity parameter. $S$ measured in $\left.\mathrm{K}(\mathrm{W} \mathrm{m})^{-2}\right)^{-1}$ is defined as the change in global mean surface temperature $(\Delta T)$ divided by the change in effective radiative forcing of the AIS.

First we calculate

$S_{\text {[Antarctica }]}=\frac{\Delta T_{(\alpha+\text { oro })}}{\Delta Q_{\text {Antarctica }}}$,

by prescribing the glacial properties of Antarctica at constant atmospheric $\mathrm{CO}_{2}$. Second, we calculate

$S_{\left[\text {Antarctica, } \mathrm{CO}_{2}\right]}=\frac{\Delta T_{\left(\alpha+\text { oro }+\mathrm{CO}_{2}\right)}}{\Delta Q_{\mathrm{CO}_{2}}+\Delta Q_{\text {Antarctica }}}$

by reducing the atmospheric $\mathrm{CO}_{2}$ from 1120 to $560 \mathrm{ppm}$ and removing the AIS.

In what follows, we will refer the reader to Table 1, which describes the different experiments for the Eocene and modern presented in the results section including all values for ESS and $S$.

\section{Results}

\subsection{Sensitivity to Antarctica ice sheet in modern and Eocene}

In general, glaciation cools the modern more than the Eocene (Table 1). The modern Antarctic glacier experiment in which only albedo is changed (Table $1, \alpha$ cases), has a $\Delta T_{(\alpha)}=-1.14$ to $-0.86 \mathrm{~K}$, while the corresponding Eocene experiment (Table $1, \alpha$ cases) has $\Delta T_{(\alpha)}=-0.36$ to $-0.27 \mathrm{~K}$. When considering the sensitivity to both components of ice sheet growth, which we have done at a range of $\mathrm{CO}_{2}$ values, we find that the Eocene has a $\Delta T_{(\alpha+\text { oro })}=-0.17$ to $-0.29 \mathrm{~K}$ while the modern has a $\Delta T_{(\alpha+\text { oro })}=-0.18$ to $-1.22 \mathrm{~K}$ (Table $1, \alpha+$ oro cases).

The results mentioned above can be summarized clearly in Fig. 4, where we plot the mean annual temperature (MAT) 


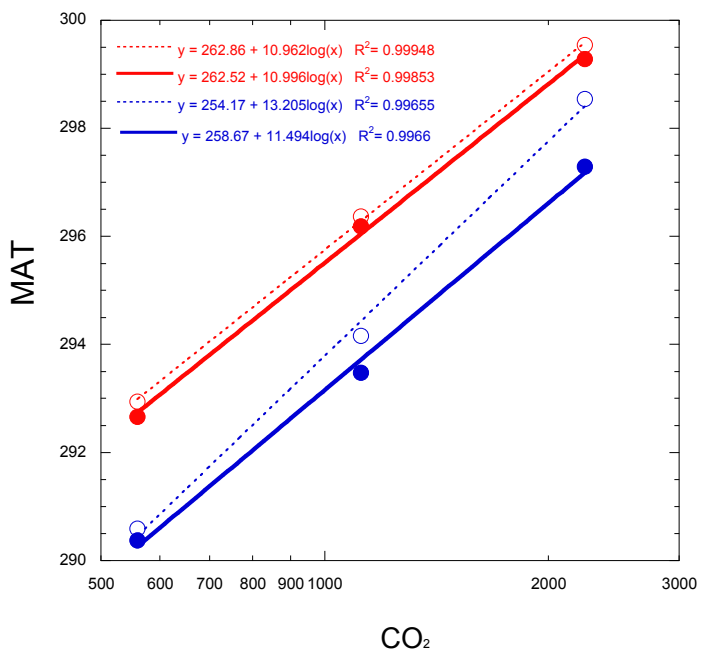

Fig. 4. The unfilled red circles represent the Eocene unglaciated simulations, while the filled red circles represent Eocene glaciated $(\alpha+$ oro) simulations. The unfilled blue circles represent the modern unglaciated simulations, while the filled blue circles represent modern glaciated $\left(\alpha+\right.$ oro) simulations. The atmospheric $\mathrm{CO}_{2}$ levels in ppm $(560,1120,2240)$ is plotted on a logarithmic scale on $\mathrm{x}$ axis and the MAT $(\mathrm{K})$ for the glaciated and unglaciated simulations is plotted along the y-axis. A logarithmic line is fitted through the unglaciated and glaciated Eocene and modern cases and the slope, y-intercept, and $R^{2}$ values are reported.

of the Eocene and modern unglaciated and glaciated simulations across a range of atmospheric $\mathrm{CO}_{2}$. The slope of the different MAT values for the glaciated versus unglaciated Eocene simulations is identical (Fig. 4). Comparing the modern glaciated and unglaciated simulations at 560 and $1120 \mathrm{ppm} \mathrm{CO} \mathrm{CO}_{2}$ results in a MAT change $(0.18-0.68 \mathrm{~K}) \mathrm{com}-$ pared to the MAT change of $1.22 \mathrm{~K}$ that occurs at $2240 \mathrm{ppm}$ $\mathrm{CO}_{2}$. At lower atmospheric $\mathrm{CO}_{2}$ (560 and 1120) when we remove the AIS in the modern, our imposed albedo change is offset by increased snowfall (compared to the glaciated modern simulations) over central Antarctica. The increased snowfall occurs because of elevated moisture transport into Antarctica because the katabatic winds are reduced as the elevation over Antarctic is decreased resulting in onshore flow. The unglaciated modern simulations end up having a larger slope compared to the glaciated modern simulations across all $\mathrm{CO}_{2}$ levels (Fig. 4) as the unglaciated modern case at 2240 warms more than the equivalent glaciated modern case. While at $2240 \mathrm{ppm} \mathrm{CO}_{2}$ the Antarctic temperatures are above freezing and the snow disappears leading to a much larger temperature sensitivity to the AIS in the modern (Fig. 4). The increases in snowfall over Antarctica does not occur in the Eocene low $\mathrm{CO}_{2}$ cases because the Eocene cases are systematically warmer than the equivalent modern cases leading to above freezing temperatures in austral summer over Antarctica at all $\mathrm{CO}_{2}$ levels.
Initial inspection of the $\triangle \mathrm{FSNT}$ and $\triangle \mathrm{FSNS}$ allows us to explore whether the models are in radiative equilibrium. Here we find that the surface change $\triangle \mathrm{FSNS}$ is approximately the same as $\triangle$ FSNT at the TOA (Hansen et al., 1981, 1997) (Table 1 , Fig. 5a) and this value scales with $\Delta T$ (Fig. 5b, Table 1). In fact, across the breadth of simulations conducted for Eocene and modern the surface and TOA short-wave radiation indicate steady state equilibrium, although there is some scatter on the order of $0.1 \mathrm{~K}\left(\mathrm{~W} \mathrm{~m}^{-2}\right)^{-1}$ (Fig. 5a) (Table 1). Below we explain that the non-local changes induced by adding the Antarctic ice sheet are different between Eocene and modern.

An analysis of Antarctica itself is necessary to separate forcing from response to establish sensitivity. When we compare the weighted temperature change $\Delta T$ Antarctica and the globally weighted effective forcing of the Antarc-

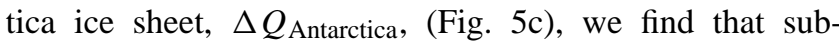
stantial cooling occurs over Antarctica due to glaciation in both configurations, although far less local cooling occurs in the 2240 Eocene case than the comparable modern case (Fig. 5c). But this comparison yields very different results of $\Delta Q_{\text {Antarctica }}$ compared to $\Delta T$ (Fig. 5d). Interestingly, the $\Delta Q_{\text {Antarctica }}$ does not translate into a significant change in global $\Delta T$ in the Eocene (Fig. 5d). Something is clearly offsetting the cooling caused by Antarctic perturbations that causes substantial cooling in the modern (Fig. 5d). Below we show that less sea ice and negative cloud feedback processes dampens the cooling in the Eocene compared to the modern. Similar comparisons were completed between $\Delta T$ Antarctica and $\Delta Q_{\text {Antarctica }}$, using FSNS and the general patterns of our results are robust (figure not shown) except, in some modern cases, $\Delta Q_{\text {Antarctica }}$ ends up being smaller at the surface compared to the TOA (Table 1), which will become important when calculating $S$.

Differing feedbacks have important implications for $S$ in modern and Eocene configurations. Calculations using Eq. (9) reveal that the modern and Eocene glacier simulations produce a wide range of values for $S_{\text {[Antarctica] }}$ in response to Antarctic glaciation holding a constant atmospheric $\mathrm{CO}_{2}$. On average for the Eocene cases, $\Delta Q_{\text {Antarctica }}$ ends up being smaller $\left(\sim-1.12 \mathrm{~W} \mathrm{~m}^{-2}\right)$ compared to $\Delta Q_{\text {Antarctica }}$ for the modern cases $\left(\sim-1.50 \mathrm{~W} \mathrm{~m}^{-2}\right)$. This difference ends up affecting the value for $S$, which on average is $\sim 0.45 \mathrm{~K}\left(\mathrm{~W} \mathrm{~m}^{-2}\right)^{-1}$ for $S_{\text {[Antarctica] }}$ for the Eocene and $\sim 0.67 \mathrm{~K}\left(\mathrm{~W} \mathrm{~m}^{-2}\right)^{-1}$ for the modern.

\subsection{Antarctic glacier induced feedback response in the modern and Eocene}

To investigate the differences in the cloud response between modern and Eocene, we examine the global change in the cloud and temperature fields. Clouds respond differently to surface perturbations in modern and paleoclimate simulations (Thompson and Barron, 1981; Barron, 1983; Heinemann et al., 2009). Initial boundary conditions, land-sea 

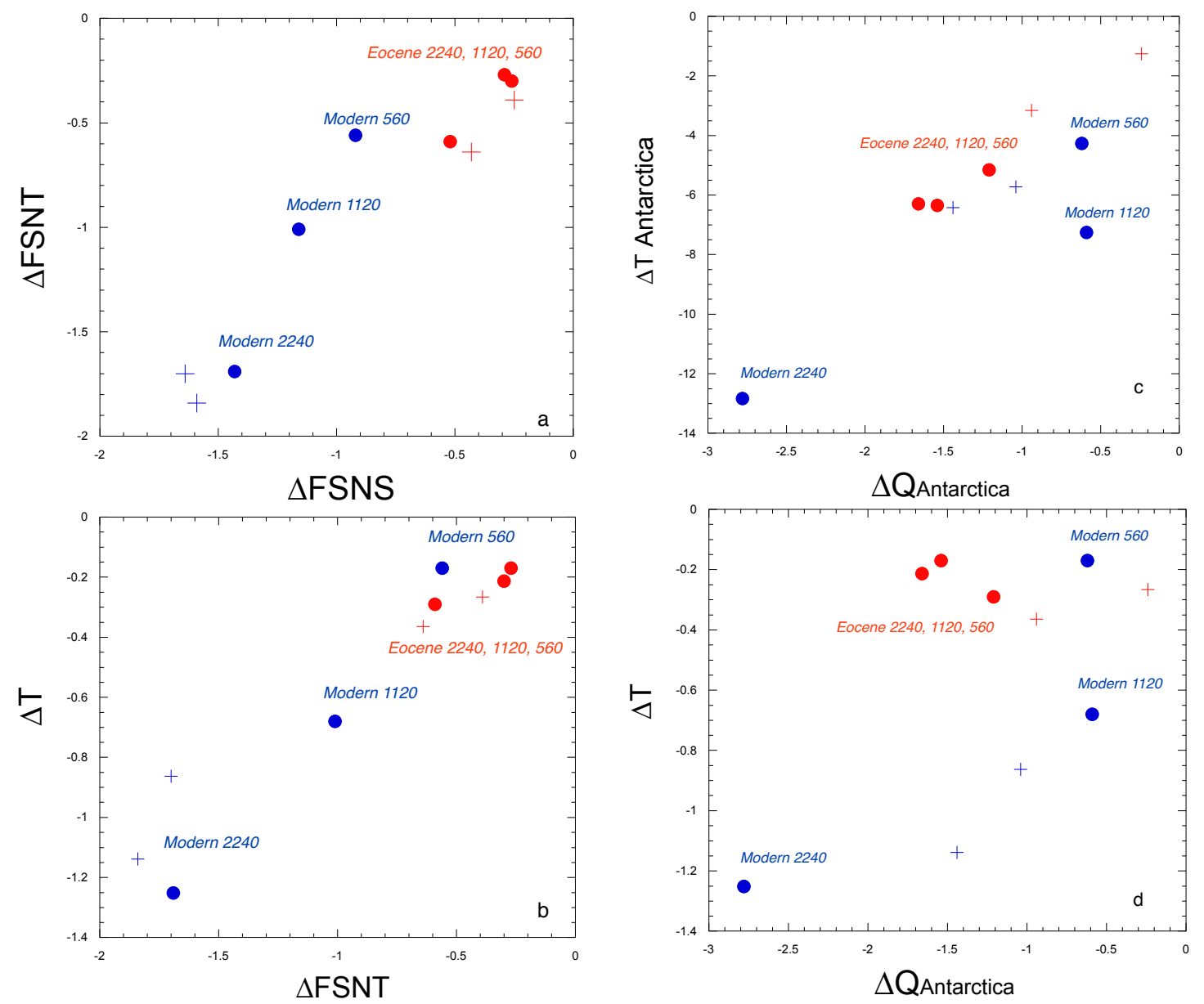

Fig. 5. The circles represent slab ocean glaciated versus unglaciated comparisons where albedo and topography are changed ( $\alpha+$ oro $)$ and labeled with their corresponding $\mathrm{CO}_{2}$ level and time period (Eocene: red, modern: blue) (Table 1). The red crosses are the Eocene (red) and modern (blue) glaciated versus unglaciated comparisons where only albedo ( $\alpha$ ) was changed (Table 1 ). (a) $\Delta \mathrm{FSNS}$ (W m ${ }^{-2}$ ) compared against $\Delta$ FSNT $\left(\mathrm{W} \mathrm{m}^{-2}\right.$ ). (b) $\Delta \mathrm{FSNT}$ compared against $\Delta T$. Same conventions as in (a, b) for (c) $\Delta Q_{\text {Antarctica }}\left(\mathrm{W} \mathrm{m}{ }^{-2}\right)$ vs. $\Delta T$ Antarctica. (d) $\Delta Q_{\text {Antarctica }}$ in $\left(\mathrm{W} \mathrm{m}^{-2}\right)$ vs. global $\Delta T$. Definitions for $\Delta Q_{\text {Antarctica }}, \Delta T, \Delta T$ Antarctica can be found in methods Sect. 2.3 .

distribution, aerosols, water vapor, $\mathrm{CO}_{2}$, and clouds end up being very important when calculating $\Delta Q_{\text {Antarctica }}$ due to imposed albedo forcings (Donohoe and Battisti, 2011; Collins et al., 2006).

As expected, the largest temperature anomaly between the glaciated and unglaciated modern and Eocene cases occurs over the Antarctic continent (Figs. 6a and 7a). Yet, in the Eocene glaciated simulations the temperatures are warmer around Antarctica compared with the unglaciated simulations (Fig. 6a). SWCF is commonly defined as the anomaly between clear-sky and cloudy-sky net downward ( $\Downarrow$ downward minus $\Uparrow$ upward) short-wave (SW) radiation (Cess et al., 1995) calculated here at the TOA. The majority of the Southern Hemisphere warms because there is an decrease in short-wave cloud forcing (SWCF) in these regions (Fig. 6b) which increases the amount of solar radiation entering the system and acts to prevent Southern Hemispheric sea ice from expanding around Antarctica (Fig. 6a). We diagnose the changes in low cloud cover (Fig. 8b) and the atmospheric greenhouse effect (Figs. 6c and 7c) which show the mechanisms that dampens the global temperature change in response to Antarctic glaciation in the Eocene.

\subsubsection{Antarctic glacier induced cloud feedback and sea ice response in the modern and Eocene}

A positive $\triangle \mathrm{SWCF}$ is dampening the cooling in the glaciated Eocene simulations (Table 1), while the SWCF anomaly for the modern cases is negative indicating a positive SWCF feedback, while in the Eocene the SWCF anomaly is positive yielding a negative SWCF feedback. As described in Kay et al. (2011), CAM4 has improved parameterizations for stratus clouds which interact with variations in surface albedo such as sea ice, and the SWCF is not only dependent on cloud fraction but on the underlying surface albedo. This will be important in understanding changes in SWCF 

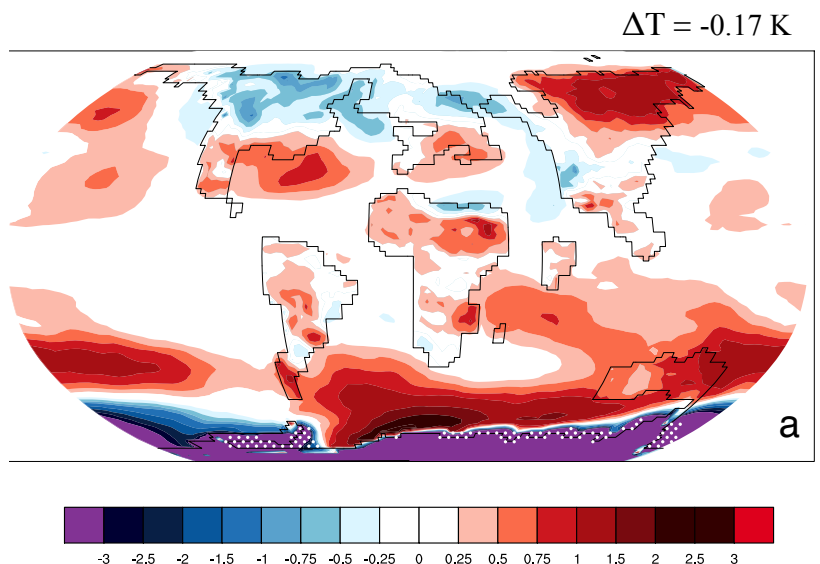

$\Delta \mathrm{SWCF}=1.29 \mathrm{Wm}^{-2}$
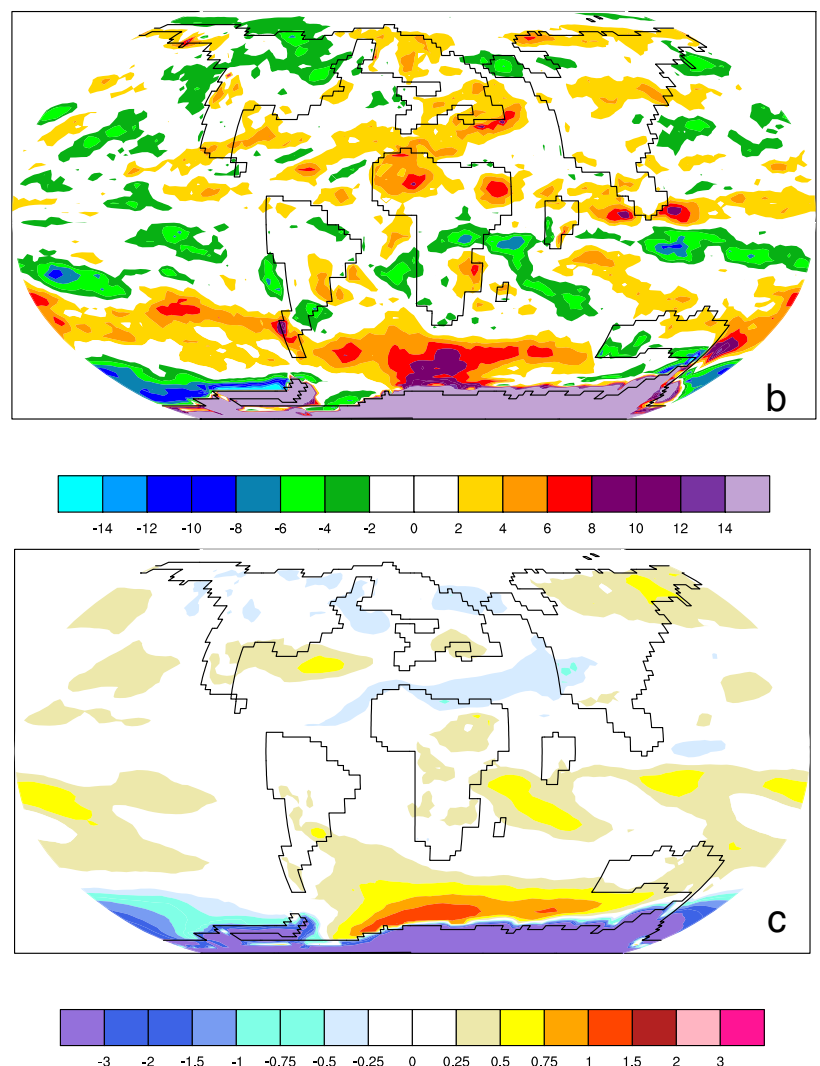

Fig. 6. Glaciated minus unglaciated Eocene simulation at $1120 \mathrm{ppm}$ $\mathrm{CO}_{2}((\alpha+$ oro $)$ experiment highlighted with a dark grey shade $)$ in Table 1. (a) Annually averaged anomalies for surface temperature (K) as the contour and the sea ice anomalies stippled in white, (b) short-wave cloud forcing (SWCF) in $\mathrm{W} \mathrm{m}^{-2}$, and (c) normalized $g_{\mathrm{a}}$ (greenhouse effect without clouds) anomaly in \%. The calculation for $g_{\mathrm{a}}$ is described in results Sect. 3.2.2, Eq. (11).

as the sea ice shifts between the glaciated and unglaciated simulations.

The SWCF anomalies in the Eocene simulations indicate less reflection by clouds in the glaciated cases, whereas in all the modern experiments the clouds are reflecting more

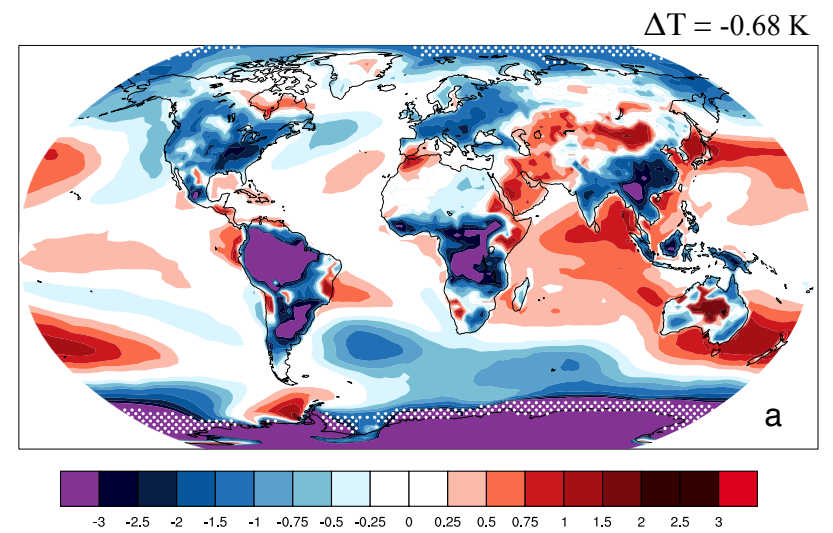

$\Delta \mathrm{SWCF}=-0.37 \mathrm{Wm}^{-2}$
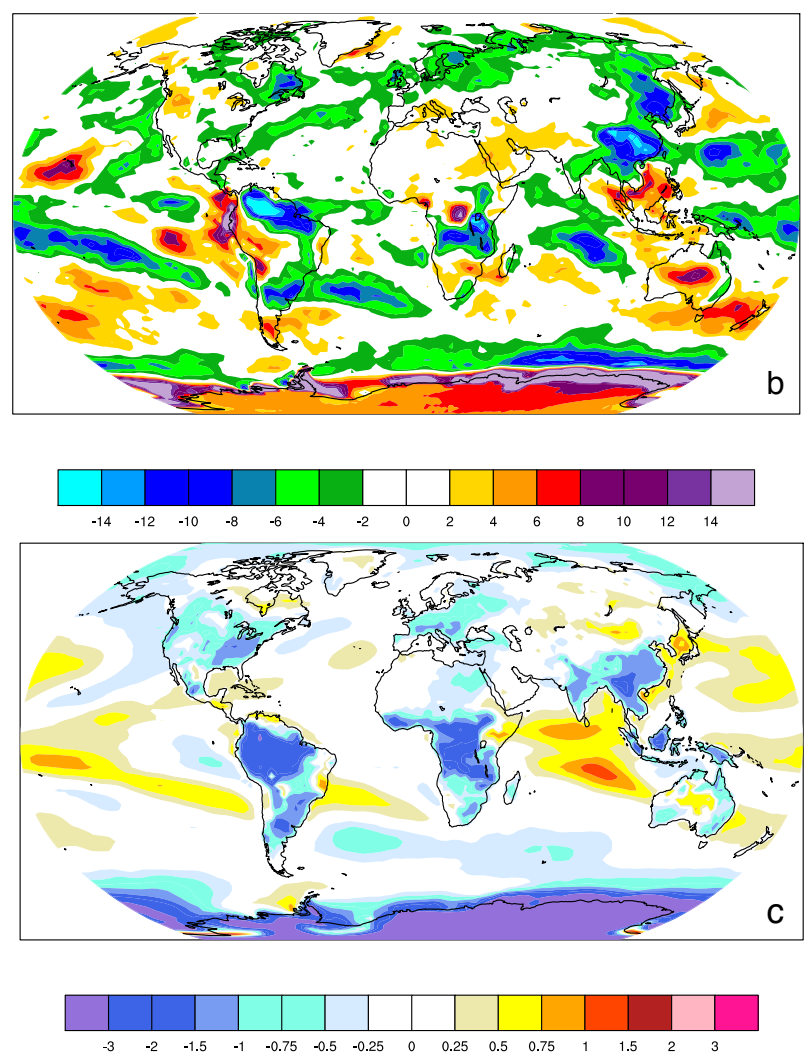

Fig. 7. Glaciated minus unglaciated modern simulation at $1120 \mathrm{ppm}$ $\mathrm{CO}_{2}((\alpha+$ oro $)$ experiment highlighted with a light grey shade $)$ in Table 1. (a) Annually averaged anomalies for surface temperature anomalies $(\mathrm{K})$ as the contour and the sea ice anomalies stippled in white, (b) short-wave cloud forcing (SWCF) in $\mathrm{W} \mathrm{m}^{-2}$, and (c) normalized $g_{\text {a }}$ (greenhouse effect without clouds) in $\%$. The calculation for $g_{\mathrm{a}}$ is described in results Sect. 3.2.2, Eq. (11).

incoming radiation in the glaciated cases (Fig. 8a). The SWCF anomalies act to warm the glaciated Eocene simulation in the southern ocean and cool nearly all the modern glaciated simulations. One exceptional modern case exists when $\left(\mathrm{CO}_{2}=2240 \mathrm{ppm}\right)$ the $\triangle \mathrm{SWCF}$ reverses sign and becomes Eocene-like, but the cooling is nevertheless very 

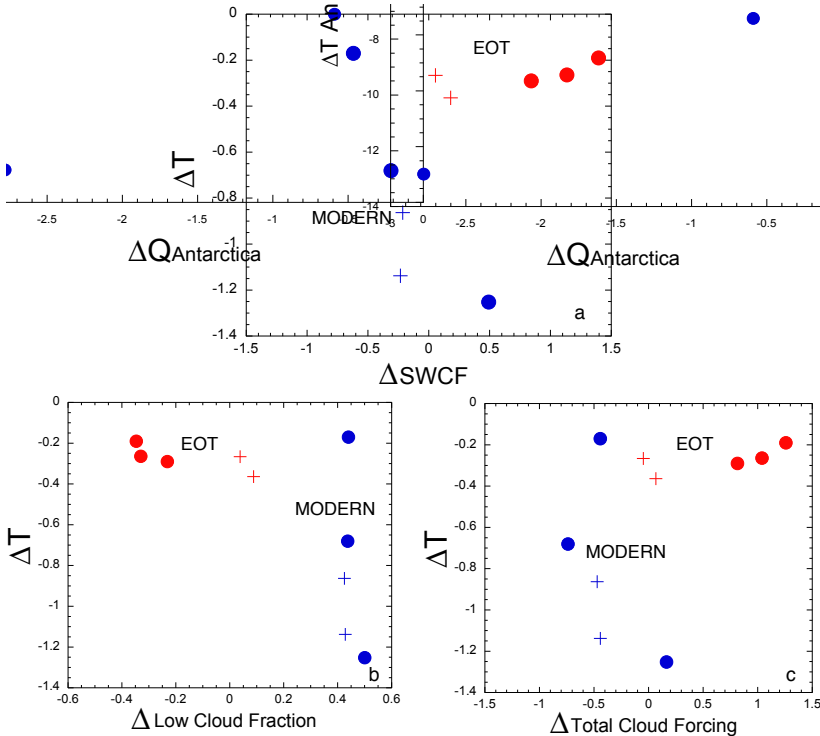

Fig. 8. Cloud related variables plotted with same conventions as Fig. 5. (a) The anomalous SWCF $\left(\mathrm{W} \mathrm{m}^{-2}\right)$ compared with $\Delta T$. (b) The low cloud fraction anomaly in (\%) (averaged from $60^{\circ} \mathrm{S}$ to $90^{\circ} \mathrm{N}$ ) compared with $\Delta T$. (c) The total cloud forcing anomaly $\left(\mathrm{W} \mathrm{m}^{-2}\right)$ compared with $\Delta T$.

strong and still linearly related to effective TOA forcing. In this high $\mathrm{CO}_{2}$ modern case, the sea ice response in the Southern Hemisphere is large (Fig. 9c and d), more than offsetting the change in the SWCF.

Changes in SWCF primarly involves shifts in low clouds (Fig. 8b). The glaciated Eocene simulations have less low clouds than the respective unglaciated simulations from $60^{\circ} \mathrm{S}$ to $90^{\circ} \mathrm{N}$ (Fig. 8b). In the modern cases there are increases in low cloud cover especially in the tropical regions with glaciation. We averaged over this latitude range because decreasing Antarctic topography results in a significant decrease in low clouds over Antarctic. To verify that the global low cloud response is not just because low clouds decrease over Antarctica, we globally average the low cloud response over all regions except Antarctica and show that the cloud response globally results in less low clouds for the Eocene and more low clouds for the modern (Fig. 8b). The total cloud forcing behaves essentially identically to the SWCF (Fig. 8c). To confirm this conclusion, plotting the zonal mean of low cloud fraction and SWCF from $60^{\circ} \mathrm{S}$ to $90^{\circ} \mathrm{N}$ shows that the Eocene generally has a positive SWCF and a reduction in low cloud fraction, while the modern simulations generally have a negative SWCF and an increase in low cloud fraction especially in the tropical regions (figure not shown).

We can summarize the differences in clouds and sea ice by calculating the feedback response for

$\lambda_{\mathrm{swcf}}=\left(\frac{\Delta \mathrm{SWCF}}{\Delta T}\right)$

and
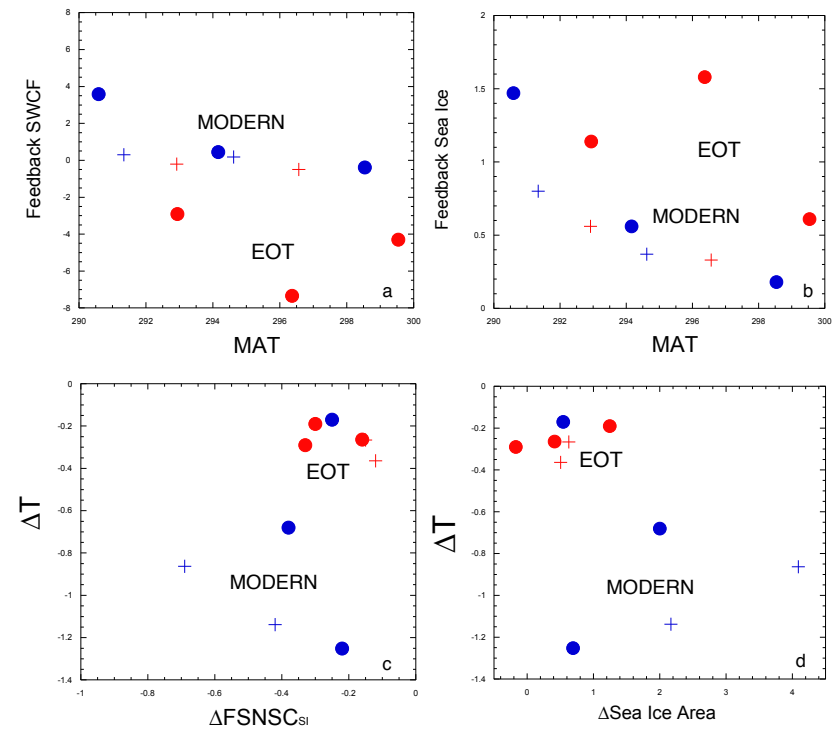

Fig. 9. Feedback related variables plotted with same conventions as Fig. 5. (a). The SWCF feedback $\left(\mathrm{W} \mathrm{m}^{-2} \mathrm{~K}^{-1}\right)$ using Eq. (6) described in Sect. 3.2.1 is plotted against the MAT of the unglaciated simulations. (b) The sea ice feedback ( $\mathrm{W} \mathrm{m}^{-2} \mathrm{~K}^{-1}$ ) using Eq. (7) described in Sect. 3.2.1, plotted against the MAT of the unglaciated simulations, (c) $\triangle$ FSNSC $_{S I}$ compared with $\Delta T$, (d) anomalous sea ice area $\left(1 \times 10^{6} \mathrm{~m}^{2}\right)$ plotted against $\Delta T$.

$\lambda_{\text {sea ice }}=\left(\frac{\Delta \mathrm{FSNSC}_{\mathrm{SI}}}{\Delta T}\right)$

in $\mathrm{W} \mathrm{m}^{-2} \mathrm{~K}^{-1}$ (Eq. 7). To calculate the sea ice feedback (Eq. 7), we must first calculate the globally weighted change in short-wave forcing due to the sea ice feedback in the Southern Hemisphere. This value is calculated the same way as Eq. (2) in Sect. 2.3, except the weighted sum of the $\triangle \mathrm{FSNSC}$ values are done over the area where only sea ice anomalies occur

$\Delta \mathrm{FSNSC}_{\mathrm{SI}}=\Delta \mathrm{FSNSC}_{\text {Sea Ice Landmask }} \cdot \mathrm{SL}$

and the SL ratio is modified to only include the areas of sea ice (Eq. 8). We calculated the sea ice forcing in the Northern Hemisphere, but found this value to be negligible in the global mean in all cases so it will not be included in the results.

The Eocene glacier simulations have a negative SWCF feedback, whereas in the modern glacier simulations there is generally a positive SWCF feedback response (Fig. 9a). This is consistent with the SWCF anomalies presented in Table 1 and the change in low cloud cover (Fig. 8b), which illustrate that in response to glaciation, the Eocene has a reduction in low cloud cover and a negative SWCF feedback. The sea ice feedback is positive in all cases, but the magnitude of this feedback is much reduced (Fig. 9b) compared to the SWCF feedback. Thus the low cloud feedback in the Eocene simulations dominates over the sea ice feedback and acts to offset 
the cooling impact of adding the Antarctic ice sheet, whereas in the modern the SWCF feedback and sea ice feedback are positive acting to enhance the cooling. This change in the modern acts to reflect more radiation in the Southern Hemisphere allowing for more sea ice area (Fig. 9d) and an increased radiative response to the sea ice growth (Fig. 9c).

\subsubsection{Antarctic glacier induced greenhouse effect in the modern and Eocene}

This analysis has focused on short-wave forcings, but longwave responses may also play a role in determining the temperature response to glaciation (Abbot et al., 2009). To explore the atmospheric greenhouse effect without the inclusion of clouds, we use the diagnostic framework of Ramanathan and Inamdar (2006).

$F_{\mathrm{c}}=\sigma T_{\mathrm{s}}^{4}-G_{\mathrm{a}}$

is the clearsky outgoing long-wave radiation $\left(\mathrm{W} \mathrm{m}^{-2}\right), T_{\mathrm{S}}$ is surface temperature, $\sigma$ is the coefficient in the StefanBoltzmann equation, and $G_{\mathrm{a}}$ is the greenhouse effect without the inclusion of clouds (Eq. 9). Rearranging to include the long-wave cloud forcing, we can re-write Eq. (9), where $G=G_{\mathrm{a}}+\mathrm{LWCF}$ and

$F=\sigma T_{\mathrm{s}}^{4}-G$

now equals the outgoing long-wave radiation for cloudy skies giving us an expression for the greenhouse effect with the inclusion of clouds (Eq. 10). For our purposes, we want to solve for $G_{\mathrm{a}}$, which is the greenhouse effect without the inclusion of clouds. We can then normalize $G_{\mathrm{a}}$ by $\sigma T_{\mathrm{s}}^{-4}$ to get a value, $g_{\mathrm{a}}$, which removes the variations in $T$ from the greenhouse effect (Eq. 11) (Ramanathan and Inamdar, 2006).

$g_{\mathrm{a}}=\frac{G_{\mathrm{a}}}{\sigma T_{\mathrm{s}}^{4}}$

In Fig. 6c, we show this normalized percentage for $g_{a}$ as an anomaly for the Eocene and the areas of warming in the Southern Hemisphere (Fig. 6a) are associated with an increase in the greenhouse forcing. The globally weighted average for the $g_{\text {a }}$ anomaly is negligible, around a tenth of a percent, but the regional changes in greenhouse effect explain some of the warming occurring in the Southern Hemisphere (Fig. 6c).

In the modern glacier simulations a clearer pattern emerges over the tropical terrestrial surfaces which cool significantly and the decreases in temperature align with a reduction in the greenhouse forcing (Fig. 7c). This is not the case in the Eocene glaciated simulation as there is little change in the greenhouse effect over the terrestrial land surfaces (Fig. 6c). In addition, in the modern glaciated simulations there are decreases in the greenhouse effect in the Southern Hemisphere (Fig. 7c), especially around South America and Africa where in the Eocene glaciated cases there is an increase in the greenhouse effect (Fig. 6c).

\section{Discussion}

\subsection{Antarctic glacier response in Eocene and modern}

This study finds that the global mean effective forcing due to the AIS is nearly constant at $\sim 1.2 \mathrm{~W} \mathrm{~m}^{-2}$ in the Eocene, regardless of $\mathrm{CO}_{2}$ level, whereas the effective forcing increases from 0.6 to $3.8 \mathrm{~W} \mathrm{~m}^{-2}$ as $\mathrm{CO}_{2}$ increases in the modern cases. When we average the global temperature anomalies for all ( $\alpha+$ oro) simulations the global cooling in the Eocene is much less $(\sim 0.25 \mathrm{~K})$ than the modern world $(\sim 0.72 \mathrm{~K})$. Additionally, cooling in the Eocene is substantially less than in the modern with comparable effective forcing values. In the Eocene, regional impacts due to glaciation in the Southern Hemisphere are large but, globally the changes are negligible. In the modern, positive feedbacks overwhelm negative feedbacks and cooling is more widespread. The larger $\Delta T(\sim 0.72 \mathrm{~K})$ in the modern simulations (as opposed to $\sim 0.25 \mathrm{~K}$ in the Eocene cases) is related to positive cloud (Fig. 9a) and sea ice feedbacks (Fig. 9b). The positive seaice feedback in the modern (Fig. 9b) act in conjunction with positive cloud feedbacks. While in the Eocene, the negative cloud feedbacks dominate over the positive sea-ice feedbacks leading to little global mean temperature change. In the Eocene, cooling is substantial in some parts of the South $\mathrm{Pa}$ cific Ocean and in some continental interiors in the Northern Hemisphere, but this cooling is nearly offset by substantial ( $\sim 3.0 \mathrm{~K}$ ) warming over the subtropical ocean, the South Atlantic and Northern Eurasia.

\subsection{Antarctic glacier response in Eocene and modern and comparison with previous work}

To our knowledge no recent climate modelling study has focused explicitly on calculating the climate sensitivity to the removal and addition of the AIS in Eocene and modern contexts, so exact comparison with prior work is not possible. Nevertheless, we can compare the results generally with other studies and provide context for the physical processes explored in this study. We discuss each type of previous study in turn, below.

The coupled atmosphere-ice sheet modelling of DeConto and Pollard (2003) and DeConto et al. (2007) is the closest modelling approach to that tried here although those studies were focused on a different problem and did not present results showing how global mean temperature was affected by the AIS. Interestingly, those studies show a $\Delta T$ of $0.80 \mathrm{~K}$ from such a perturbation (DeConto, personal communication), which is significantly larger than the Eocene results presented here, although within the range of modern values we have calculated. This result also involved changes in Earth's orbital parameters, which also influences global mean temperature. This makes it difficult to directly compare with our results, but based on our own preliminary work where we changed obliquity and glaciation like the Deconto 
and Pollard simulations, we estimate that half of the $0.80 \mathrm{~K}$ cooling could be due to orbital changes and not to the ice sheet itself. In this case DeConto's results maybe similar to ours.

The importance of forcing factors and feedbacks for which no proxies exist also complicates attempts at evaluating model predictions with proxies across the EOT although some general statements can be made. The temperature change associated with adding the AIS and dropping atmospheric $\mathrm{CO}_{2}$ by $560 \mathrm{ppm}$ produces a good match for the cooling detected in the proxy record, especially the Southern Hemisphere ODP sites 277, 511, and 689 (Liu et al., 2009; Macksensen and Ehrmann, 1992) and the cooling in the Northern Hemisphere sites 913, 336, 643, and 985 (Liu et al., 2009; Eldrett et al., 2009) as the model cools $\sim 5 \mathrm{~K}$ in these high latitude regions. This combined change is also able to match the terrestrial record temperature drop of 3-8 K over North America (Zanazzi et al., 2007) as the model produces $\sim 6 \mathrm{~K}$ cooling over North America, whereas adding the AIS at constant atmospheric $\mathrm{CO}_{2}$ produces warming in the Southern Hemisphere (outside of Antarctica itself) in contrast to the proxy record described above. This highlights the importance in $\mathrm{CO}_{2}$ forcing for causing cooling at the EOT (Pagani et al., 2011; DeConto and Pollard, 2003). These results also suggest that CESM1.0 has overly strong negative feedbacks (or too weak, or neglected positive feedbacks) given that a larger than reconstructed drop of $\mathrm{CO}_{2}$ from 1120 to 560 and the growth of a large AIS is required to cool the Eocene simulations by $3.7 \mathrm{~K}$. A model-derived ESS is $1.05 \mathrm{~K}\left(\mathrm{~W} \mathrm{~m}^{-2}\right)^{-1}$, as compared with the value of $\sim 1.5 \mathrm{~K}\left(\mathrm{~W} \mathrm{~m}^{-2}\right)^{-1}$ calculated from EOT proxies (see Sect. 1.1). The difference is however within the substantial uncertainty of the proxy records.

Hansen and Nazarenko (2004) found that although forcings may have similar magnitudes this may not translate into identical changes in global mean temperature. They define an "efficacy" term as the global temperature change per unit forcing for a chosen climate variable compared with the standard $\mathrm{CO}_{2}$ forcing (Hansen et al., 2005). A major conclusion of these studies is that efficacy values for different forcings is not expected to be constant between different climate states. Here we have found that the efficacy of climate forcing due to introduction of the AIS in our simulations is not constant and the climate change in the Eocene due to the AIS is much smaller than one would expect from a similar $\mathrm{W} \mathrm{m}^{-2}$ forcing of $\mathrm{CO}_{2}$. Using values from Table 1 , we calculate that the efficacy of the modern glaciated to unglaciated 1120 simulation is 0.36 , while the same comparison in the Eocene is $\sim 0.03$. This has implications for previous work which estimate past changes in surface albedo forcing at the EOT compared to modern to be $\sim 2\left(\mathrm{~W} \mathrm{~m}^{-2}\right)$ (Hansen and Sato, 2012; Hansen et al., 2008) with the assumption that efficacy of ice albedo forcing is the same as modern day (Skinner, 2012), contrary to our results. This further complicates how to infer surface albedo forcing and sensitivity in paleoclimate time periods.
Lunt et al. (2012) conducted a recent study in which they altered Greenland and Antarctic topography and albedo in Pliocene contexts and found that the regional impacts of these alterations was significant, but the global response to these variables was weak ( $\sim 10 \%$ of the total, or $\sim 0.30 \mathrm{~K}$ ). Other Pliocene modelling studies have focused on understanding the role of the Greenland Ice Sheet in affecting climate sensitivity (Lunt et al., 2008; Koenig et al., 2011). Their results found that the Greenland Ice Sheet has strong regional control on temperature sensitivity, but the global impact to changing the Greenland Ice Sheet is negligible.

So, in short the estimated effective forcing and global mean temperature changes are well within those expected from prior work, but an exact comparison is currently impossible. Additional simulations invoking similar experimental methodologies and diagnostics are required to ascertain whether our results are robust or strongly model dependent. Given the importance of low clouds to our results, it is likely that the results of this study will only be as robust as the spread of model differences in the representation of low clouds.

\section{Conclusions}

We have calculated $S_{\text {[Antarctica] }}$ due to the removal of the AIS using a global climate model in modern and Eocene contexts. To date, no climate modelling study has separated the AIS component in terms of $S_{\text {[Antarctica] }}$ for these time periods, and we hope the results can be used to compare against proxy data derived climate sensitivity estimates. In the future it will be important for modelling groups to simulate AIS sensitivity using different climate models, at varying resolutions, using different cloud parameterizations, and with a fully interactive ocean model to evaluate the robustness of the results presented in this study.

The results lead to 5 major conclusions about the climatic impacts of the AIS in modern and Eocene climate. The results we use to draw our conclusions are derived from one model framework and the results should be taken within this context.

1. Very little of the temperature difference between modern and Eocene is explained by Antarctic glaciation.

2. The results illustrate that the efficacy of AIS forcing in the Eocene is not necessarily close to one and is likely to be model and state dependent.

3. Antarctic glaciation induces a reduction in low clouds from $60^{\circ} \mathrm{S}$ to $90^{\circ} \mathrm{N}$ in the Eocene simulations while in the modern there are increases in low clouds from $60^{\circ} \mathrm{S}$ to $90^{\circ} \mathrm{N}$.

4. Adding the AIS to the Eocene greenhouse climate has a strong negative low cloud feedback response resulting in minimal global cooling even though the $\Delta Q_{\text {Antarctica }}$ 
is substantial. The results suggests that Antarctic glaciation at the EOT transition may not have had a significant global temperature response because of negative feedbacks.

5. Removing the AIS in the modern simulations at 560 and $1120 \mathrm{ppm} \mathrm{CO}_{2}$ has a reduced temperature sensitivity compared to the removing the glacier at $2240 \mathrm{ppm}$ because our imposed albedo change (at the lower $\mathrm{CO}_{2}$ levels) is offset by increased snowfall and year round freezing temperatures over Antarctica.

The importance of model dependence - especially to the low cloud parameterization - is one of the main lessons of this study. Acknowledging the fact that this is only one particular model and an idealized study, we can nevertheless conclude for this one model - that growth of Antarctic land ice played little role directly or through fast feedbacks in cooling the world at the EOT $(<0.25 \mathrm{~K})$. In this model, the Antarctic ice sheet at the EOT plays a relatively minor role in global mean climate change. In the modern the cloud and sea-ice feedbacks induced by Antarctic glaciation enhance the global cooling response.

The reality is that if ice sheets impacts on climate are strongly mediated by poorly constrained, fast cloud feedbacks then models are likely to give divergent results to ice sheet forcing. The results of this study indicate that the feedbacks involved may be strongly state dependent - i.e. the Eocene is not a good analogue for the modern (Haywood et al., 2011; Francis and Williams, 2011; Huber, 2013) - in which case calculating ESS across the EOT may have little direct value for making inferences about the future. This also specifically suggests that there may not be much gained by using proxy data records from the EOT and projecting by analogy into the future because unravelling the different forcings and feedbacks in the past can not be done from proxy records. Since there are no cloud proxies, these neglected cloud feedbacks will be incorrectly attributed instead to the processes observed in the proxy record, thus leading to inflated or reduced estimates of paleoclimate feedbacks. Instead, progress will likely rely on using proxies from the EOT to discriminate between models that match proxies and those that do not and using those models to project into the future.

Acknowledgements. We acknowledge support of the Computational Sciences and Engineering (CS\&E) program which supported the first author through a GAANN fellowship. The authors would like to thank two anonymous reviewers, Dorian Abbot and Jonathan Buzan for helpful discussions and comments during the preparation of the manuscript. The authors would also like to thank Christine Shields and the other paleoclimate working group members at NCAR who helped with some of the implementation of the Eocene simulations. In addition, parts of this research were funded by NSF P2C2 grants 0902882 and 0902780 . This is PCCRC paper number 1219.
Edited by: A. Haywood

\section{References}

Abbot, D. S., Huber, M., Bousquet, G., and Walker, C. C.: High$\mathrm{CO}_{2}$ cloud radiative forcing feedback over both land and ocean in a global climate model, Geophys. Res. Lett., 36, L05702, doi:10.1029/2008GL036703, 2009.

Ali, J. R. and Huber, M.: Mammalian biodiversity on Madagascar controlled by ocean currents, Nature, 463, 653-656, doi:10.1038/nature08706, 2010.

Barron, E. J.: A warm, equable cretaceous: the nature of the problem, Earth-Sci. Rev., 19, 305-338, doi:10.1016/00128252(83)90001-6, 1983.

Bitz, C. M., Shell, K. M., Gent, P. R., Bailey, D., Danabasoglu, G., Armour, K. C., Holland, M. M., and Kiehl, J. T.: Climate sensitivity of the community climate system model version 4, J. Climate, 25, 3053-3070, doi:10.1175/JCLI-D-11-00290.1, 2012.

Boer, G., Chapman, W., Kay, J. E., Medeiros, B., Shupe, M. D., Vavrus, S., and Walsh, J.: A characterization of the presentday arctic atmosphere in CCSM4, J. Climate, 25, 2676-2695, doi:10.1175/JCLI-D-11-00228.1, 2012.

Boer, G. J. and Yu, B.: Climate sensitivity and climate state, Clim. Dynam., 21, 167-176, doi:10.1007/s00382-003-0323-7, 2003.

Bohaty, S. M., Zachos, J. C., and Delaney, M. L.: Foraminiferal $\mathrm{Mg} / \mathrm{Ca}$ evidence for Southern Ocean cooling across the Eoceneoligocene transition, Earth Planet. Sc. Lett., 317, 251-261, doi:10.1016/j.epsl.2011.11.037, 2012.

Brady, E. C., Otto-Bliesner, B. L., and Rosenbloom, N.: Sensitivity to glacial forcing in the CCSM4, J. Climate, submitted, 2012.

Briegleb, B. P. and Light, B.: A Delta-Eddington multiple scattering parameterization for solar radiation in the sea ice component of the Community Climate System Model, NCAR Tech. Note NCAR/TN-472+STR, National Center for Atmospheric Research, 2007

Cess, R. D., Zhang M. H., Minnis, P., Corsetti, L., Dutton, E. G., Forgan, B. W., Garber, D. P., Gates, W. L., Hack, J. J., Harrison, E. F., Jing, X., Kiehl, J. T., Long, C. N., Morcrette, J. J., Potter, G. L., Ramanathan, V., Subasilar, B., Whitlock, C. H., Young, D. F., and Zhou, Y.: Absorption of solar radiation by clouds: observations versus models, Science, 267, 496-499, doi:10.1126/science.267.5197.496, 1995.

Chen, J. L., Wilson, C. R., Blankenship, D., and Tapley, B. D.: Accelerated Antarctic ice loss from satellite gravity measurements, Nat. Geosci., 2, 859-862, doi:10.1038/ngeo694, 2009.

Collins, W. D., Ramaswamy, V., Schwarzkopf, M. D., Sun, Y., Portmann, R., Fu, Q., Casanova, S., Dufresne, J. L., Fillmore, D., Forster, P., Galin, V., Gohar, L., Ingram, W., Kratz, D., Lefebvre, M.-P., Li, J., Marquet, P., Oinas, V., Tsushima, Y., Uchiyama, T., and Zhong, W.: Radiative forcing by well-mixed greenhouse gases: Estimates from climate models in the IPCC AR4, J. Geophys. Res., 111, D14317, doi:10.1029/2005JD006713, 2006.

Coxall, H. K., Wilson, P. A., Palike, H., Lear, C. H., and Backman, J.: Rapid stepwise onset of Antarctic glaciation and deeper calcite compensation in the Pacific Ocean, Nature, 433, 53-57, doi:10.1038/nature03135, 2005.

DeConto, R. M. and Pollard, D.: Rapid cenozoic glaciation of Antarctica induced by declining atmospheric $\mathrm{CO}_{2}$, Nature, 421 , 245-249, doi:10.1038/nature01290, 2003. 
DeConto, R. M., Pollard, D., and Harwood, D.: Sea ice feedback and cenozoic evolution of Antarctic climate and ice sheets, Paleoceanography, 22, PA3214, doi:10.1029/2006PA001350, 2007.

DeConto, R. M., Pollard, D., Wilson, P. A., Palike, H., Lear, C. H., and Pagani, M.: Thresholds for cenozoic bipolar glaciation, Nature, 455, 652-656, doi:10.1038/nature07337, 2008.

Donohoe, A. and Battisti, D. S.: Atmospheric and surface contributions to planetary albedo, J. Climate, 24, 4402-4418, doi:10.1175/2011JCLI3946.1, 2011.

Edgar, K. M., Wilson, P. A., Sexton, P. F., and Suganuma, Y.: No extreme bipolar glaciation during the main Eocene calcite compensation shift, Nature, 448, 908-911, doi:10.1038/nature06053, 2007.

Eldrett, J. S., Greenwood, D. R., Harding, I. C., and Huber, M.: Increased seasonality through the Eocene to oligocene transition in northern high latitudes, Nature, 459, 969-973, doi:10.1038/nature08069, 2009.

Francis, J. E. and Williams, M.: Are there pre-quaternary geological analogues for a future greenhouse warming?, Philos. T. Roy. Soc. A, 369, 933-956, doi:10.1098/rsta.2010.0317, 2011.

Gent, P. R., Danabasoglu, G., Donner, L. J., Holland, M. M., Hunke, E. C., Jayne, S. R., Lawrence, D. M., Neale, R. B., Rasch, P. J., Vertenstein, M., Worley, P. H., Yang, Z.-L., and Zhang, M:. The Community Climate System Model version 4, J. Climate, 24, 4973-4991, doi:10.1175/2011JCLI4083.1, 2011.

Gettelman, A., Kay, J. E., and Shell, K. M.: The evolution of climate sensitivity and climate feedbacks in the Community Atmosphere Model, J. Climate, 25, 1453-1469, doi:10.1175/JCLI-D11-00197.1, 2012.

Hambrey, M. J. and Barrett, P. J.: Cenozoic sedimentary and climatic record, Ross Sea region, Antarctica, Antar. Res. S., 60, 91-124, 1993.

Hansen, J. and Nazarenko, L.: Soot climate forcing via snow and ice albedos, P. Natl. Acad. Sci. USA, 101, 423-428, doi:10.1073/pnas.2237157100, 2004.

Hansen, J. and Sato, M.: Paleoclimate Implications for HumanMade Climate Change, edited by: Berger, A., Mesinger, F., and Sijacki, D., Springer, 21-47, doi:10.1007/978-3-7091-0973-1, 2012.

Hansen, J., Johnson, D., Lacis, A., Lebedeff, S., Lee, P., Rind, D., and Russell, G.: Climate impact of increasing atmospheric carbon dioxide, Science, 213, 957-966, doi:10.1126/science.213.4511.957, 1981.

Hansen, J., Lacis, A., Rind, D., Russell, G., Stone, P., Fung, I., Ruedy, R., and Lerner, J.: Climate sensitivity: analysis of feedback mechanisms, Meteorol. Mon., 29, 130-163, 1984.

Hansen, J., Sato, M., and Ruedy, R.: Radiative forcing and climate response, J. Geophys. Res., 102, 6831-6864, doi:10.1029/96JD03436, 1997.

Hansen, J., Sato, M., Ruedy R., et al.: Efficacy of climate forcings, J. Geophys. Res., 110, D18104, doi:10.1029/2005JD005776, 2005.

Hansen, J., Sato, M., Kharecha, P., Beerling, C., Berner, R., Masson-Delmotte, V., Pagani, M., Raymo, M., Royer, D. L., and Zachos, J. C.: Target atmospheric $\mathrm{CO}_{2}$ : Where should humanity aim?, Open Atmos. Sci. J., 2, 217-231, 2008.

Hansen, J., Ruedy, R., Sato, M., and Lo, K.: Global surface temperature change, Rev. Geophys., 48, RG4004, doi:10.1029/2010RG000345, 2010.
Hay, W.: Can humans force a return to a Cretaceous climate?, Sediment. Geol., 235, 5-26, 2011.

Haywood, A. M., Ridgwell, A., Lunt, D. J., Hill, D. J., Pound, M. J., Dowsett, H. J., Dolan, A. M., Francis, J. E., and Williams, M.: Are there pre-quaternary geological analogues for a future greenhouse warming?, Philos. T. Roy. Soc. A, 369, 933-956, 2011.

Heavens, N. G., Shields, C. A., and Mahowald, N. M.: A paleogeographic approach to aerosol prescription in simulations of deep time climate, J. Adv. Model. Earth Syst., 4, M11002, doi:10.1029/2012MS000166, 2012.

Heinemann, M., Jungclaus, J. H., and Marotzke, J.: Warm Paleocene/Eocene climate as simulated in ECHAM5/MPI-OM, Clim. Past, 5, 785-802, doi:10.5194/cp-5-785-2009, 2009.

Herold, N., Huber, M., Muller, R. D., and Seton, M.: Modelling the miocene climatic optimum: ocean circulation, Paleoceanography, 27, PA1209, doi:10.1029/2010PA002041, 2012.

Huber, M.: A sensitivity to history, Nat. Geosci., 6, 15-16, doi:10.1038/ngeo1695, 2013.

Huber, M. and Caballero, R.: The early Eocene equable climate problem revisited, Clim. Past, 7, 603-633, doi:10.5194/cp-7603-2011, 2011.

Huber, M. and Goldner, A.: Eocene monsoons, J. Asian Earth Sci., 44, 3-23, doi:10.1016/j.jseaes.2011.09.014, 2011.

Huber, M. and Nof, D.: The ocean circulation in the Southern Hemisphere and its climatic impacts in the Eocene, Palaeogeogr. Palaeocl., 231, 9-28, 2006.

Huber, M. and Sloan, L. C.: Heat transport, deep waters, and thermal gradients: coupled simulation of an Eocene greenhouse climate, Geophys. Res. Lett., 28, 3481-3484, doi:10.1029/2001GL012943, 2001.

Huber, M., Brinkhuis, H., Stickley, C. E., Doos, K., Sluijs, A., Warnaar, J., Schellenberg, S. A., and Williams, G. L.: Eocene circulation of the Southern Ocean: was Antarctica kept warm by subtropical waters?, Paleoceanography, 19, PA4026, doi:10.1029/2004PA001014, 2004.

Hunke, E. C. and Lipscomb, W. H.: CICE: the Los Alamos sea ice model users manual, Version 4, Tech. Report LA-CC-06-012j, Los Alamos National Laboratory, 2008.

Ivany, L. C., Patterson, W. P., and Lohmann, K. C.: Cooler winters as a possible cause of mass extinctions at the Eocene/oligocene boundary, Nature, 407, 887-890, doi:10.1038/35038044, 2000.

Jacob, T., Wahr, J., Pfeffer, T. W., and Swenson, S.: Recent contributions of glaciers and ice caps to sea level rise, Nature, 482, 514-518, doi:10.1038/nature10847, 2012.

Joughin, I. and Alley, R. B.: Stability of the West AIS in a warming world, Nat. Geosci., 4, 506-513, doi:10.1038/ngeo1194, 2011.

Katz, M. E., Miller, K. G., Wright, J. D., Wade, B. S., Browning, J. V., Cramer, B. S., and Rosenthal, Y.: Stepwise transition from the Eocene greenhouse to the oligocene icehouse, Nat. Geosci., 1, 329-334, doi:10.1038/ngeo179, 2008.

Kay, J. E., Raeder, K., Gettelman, A., and Anderson, J.: The boundary layer response to recent Arctic sea ice loss and implications for high-latitude climate feedbacks, J. Climate, 24, 428447, doi:10.1175/2010JCLI3651.1, 2011.

Kay, J. E., Holland, M. M., Bitz, C., Blanchard-Wrigglesworth, E., Gettelman, A., Conley, A., and Bailey, D.: The Influence of Local Feedbacks and Northward Heat Transport on the Equilibrium Arctic Climate Response to Increased Greenhouse Gas Forcing, J. Climate, 25, 5433-5450, doi:10.1175/JCLI-D-11- 
00622.1, 2012a.

Kay, J. E., Hillman, B., Klein, S., Zhang, Y., Medeiros, B., Gettelman, G., Pincus, R., Eaton, B., Boyle, J., Marchand, R., and Ackerman, T.: Exposing global cloud biases in the Community Atmosphere Model (CAM) using satellite observations and their corresponding instrument simulators, J. Climate, 25, 5190-5207, doi:10.1175/JCLI-D-11-00469.1, 2012b.

Kiehl, J.: Lessons from Earth's Past, Science, 331, 158-159, doi:10.1126/science.1199380, 2011.

Kirkevag, A., Iversen, T., Seland, Ø., Debernard, J. B., Storelvmo, T., and Kristjansson, J. E.: Aerosol-cloud-climate interactions in the climate model CAM-Oslo, Tellus A, 60, 492512, 2008

Koenig, S. J., DeConto, R. M., and Pollard, D.: Late pliocene to pleistocene sensitivity of the Greenland ice sheet in response to external forcing and internal feedbacks, Clim. Dynam., 37, 1247-1268, doi:10.1007/s00382-011-1050-0, 2011.

Lamarque, J.-F., Emmons, L. K., Hess, P. G., Kinnison, D. E., Tilmes, S., Vitt, F., Heald, C. L., Holland, E. A., Lauritzen, P. H., Neu, J., Orlando, J. J., Rasch, P. J., and Tyndall, G. K.: CAM-chem: description and evaluation of interactive atmospheric chemistry in the Community Earth System Model, Geosci. Model Dev., 5, 369-411, doi:10.5194/gmd-5-369-2012, 2012.

Lawrence, D. M., Oleson, K. W., Flanner, M. G., Fletcher, C. G., Lawrence, P. J., Levis, S., Swenson, S. C., and Bonan, G. B.: The CCSM4 land simulation, 1850-2005: assessment of surface climate and new capabilities, J. Climate, 25, 2240-2260, doi:10.1175/JCLI-D-11-00103.1, 2012.

Lear, C. H., Elderfield, H., and Wilson, P.: Cenozoic deepsea temperature and global ice volumes from $\mathrm{Mg} / \mathrm{Ca}$ in benthic foraminiferal calcite, Science, 287, 269-272, doi:10.1126/science.287.5451.269, 2000.

Lin, S. J.: A vertically Lagrangian finite-volume dynamical core for global models, Mon. Weather Rev., 132, 2293-2307, 2004.

Liston, G. E. and Hiemstra, C. A.: The changing cryosphere: panArctic snow trends (1979-2009), J. Climate, 24, 5691-5712, 2011

Liu, Z., Pagani, M., Zinniker, D., DeConto, R., Huber, M., Brinkhuis, H., Shah, S., Leckie, M., and Pearson, A.: Global cooling during the Eocene-oligocene climate transition, Science, 323, 1187-1190, doi:10.1126/science.1166368, 2009.

Lunt, D. J., Foster, G. L., Haywood, A. M., and Stone, E. J.: Late pliocene Greenland glaciation controlled by a decline in atmospheric $\mathrm{CO}_{2}$ levels, Nature, 454, 1102-1105, doi:10.1038/nature07223, 2008.

Lunt, D. J., Haywood, A. M., Schmidt, G. A., Salzmann, U., Valdes, P. J., and Dowsett, H. J.: Earth system sensitivity inferred from Pliocene modelling and data, Nat. Geosci., 3, 60-64, doi:10.1038/NGEO706, 2010.

Lunt, D. J., Haywood, A. M., Schmidt, G. A., Salzmann, U., Valdes, P. J., Dowsett, H. J., and Loptson, C. A.: On the causes of mid-pliocene warmth and polar amplification, Earth Planet. Sc. Lett., 321-322, 128-138, doi:10.1016/j.epsl.2011.12.042, 2012.

Mackensen, A. and Ehrmann, W. U.: Middle Eocene through early oligocene climate history and paleoceanography in the Southern Ocean: stable oxygen and carbon isotopes from ODP sites on Maud Rise and Kerguelen Plateau, Mar. Geol., 108, 1-27, 1992.
Miller, K. G., Fairbanks, R. G., and Mountain, G. S.: Tertiary oxygen isotope synthesis, sea-level history and continental margin erosion, Paleoceanography, 2, 1-19, 1987.

Miller, K. G., Wright, J. D., Katz, M. E., Wade, B. S., Browning, J. V., Cramer, B. S., and Rosenthal, Y.: Climate threshold at the Eocene-oligocene transition: AIS influence on ocean circulation, Geol. Soc. Am., 452, 1-10, 2009.

Mishra, S. K., Taylor, M. A., Nair, R. D., Lauritzen, P. H., Tufo, H. M., and Tribbia, J. J.: Evaluation of the HOMME dynamical core in the aqua-planet configuration of NCAR CAM4: rainfall, J. Climate, 24, 4037-4055, doi:10.1175/2011JCLI3860.1, 2011.

Myhre, G. and Myhre, A.: Uncertainties in radiative forcing due to surface albedo changes caused by land-use changes, J. Climate, 16, 1511-1524, 2003.

Myhre, G., Highwood, E. J., Shine, K. P., and Stordal, F.: New estimates of radiative forcings due to well mixed greenhouse gases, Geophys. Res. Lett., 25, 2715-2718, 1998.

Neale, R. B., Chen, C. C., Gettelman, A., Lauritzen, P. H., Park, S., Williamson, D. L., Conley, A. J., Garcia, R., Kinnison, D., Lamarque, J. F., Marsh, D., Mills, M., Smith, A. K., Tilmes, S., Vitt, F., Cameron-Smith, P., Collins, W. D., Iacono, M. J., Rasch, P. J., and Taylor, M.: Description of the NCAR Community Atmosphere Model (CAM 4.0). NCAR Technical Note NCAR/TN-XXX+STR, National Center for Atmospheric Research, Boulder, Colorado, draft, available at: http://www.cesm. ucar.edu/models/cesm1.0/cam/ (last access: 14 July 2012), 2010.

Neale, R. B., Richter, J., Park, S., Lauritzen, P. H., Vavrus, S. J., Rasch, P. J., and Zhang, M.: The mean climate of the community atmosphere model (CAM4) in forced SST and fully coupled experiments, J. Climate, submitted, 2012.

Pagani, M., Huber, M., Liu, Z., Bohaty, S. M., Henderiks, J., Sijp, W., Krishnan, S., and DeConto, R. M.: The role of carbon dioxide during the onset of Antarctic glaciation, Science, 334, 1261-1264, doi:10.1126/science.1203909, 2011.

Palaeosens members: Making sense of palaeoclimate sensitivity, Nature, 491, 683-691, doi:10.1038/nature11574, 2012.

Pearson, P. N., Foster, G. L., and Wade, B. S.: Atmospheric carbon dioxide through the Eocene-oligocene climate transition, Nature, 461, 1110-1113, doi:10.1038/nature08447, 2009.

Pritchard, H. D., Arthern, R. J., Vaughan, D. G., and Edwards, L. A.: Extensive dynamic thinning on the margins of the Greenland and Antarctic Ice Sheets, Nature, 461, 971-975, doi:10.1038/nature08471, 2009.

Pusz, A. E., Thunell, R. C., and Miller, K. G.: Deep water temperature, carbonate ion, and ice volume changes across the Eoceneoligocene climate transition, Paleoceanography, 26, PA2205, doi:10.1029/2010PA001950, 2011.

Ramanathan, V. and Inamdar, A.: The radiative forcing due to clouds and water vapor, in: Frontiers of Climate Modelling, edited by: Kiehl, J. T. and Ramanthan, V., Cambridge Univ. Press, New York, 119-151, 2006.

Roe, G. H. and Baker, M. B.: Why is climate sensitivity so unpredictable?, Science, 318, 629-632, doi:10.1126/science.1144735, 2007.

Rohling, E. J., Medina-Elizalde, M., Shepherd, J. G., Siddall, M., and Stanford, J. D.: Sea surface and high-latitude temperature sensitivity to radiative forcing of climate over several glacial cycles, J. Climate, 25, 1635-1656, doi:10.1175/2011JCLI4078.1, 
2012.

Royer, D. L., Pagani, M. and Beerling, D. J.: Geobiological constraints on Earth system sensitivity to $\mathrm{CO}_{2}$ during the Cretaceous and Cenozoic, Geobiology, 10, 298-310, doi:10.1111/j.14724669.2012.00320.x, 2012.

Scher, H. D., Bohaty, S. M., Zachos, J. C., and Delaney, M. L.: Twostepping into the icehouse: East Antarctic weathering during progressive ice-sheet expansion at the Eocene-oligocene transition, Geology, 39, 383-386, doi:10.1130/G31726.1, 2011.

Seland, Ø., Iversen, T., Kirkevag, A., and Storelvmo, T.: Aerosolclimate interactions in the CAM-Oslo atmospheric GCM and investigation of associated basic shortcomings, Tellus A, 603, 459491, 2008.

Senior, C. A. and Mitchell, J. F. B.: The time-dependence of climate sensitivity, Geophys. Res. Lett., 27, 268-2688, doi:10.1029/2000GL011373, 2000.

Sewall, J. O., Sloan, L. C., Huber, M., and Wing, S.: Climate sensitivity to changes in land surface characteristics, Global Planet. Change, 26, 445-465, doi:10.1016/S0921-8181(00)00056-4, 2000.

Sijp, W. P., England, M. H., and Huber, M.: Effect of the deepening of the Tasman Gateway on the global ocean, Paleoceanography, 26, PA4207, doi:10.1029/2011PA002143, 2011.

Skinner L.: A Long View on Climate Sensitivity, Science, 337, $917-$ 919, doi:10.1126/science.1224011, 2012.

Solomon, S., Plattner, G.-K., Knutti, R., and Friedlingstein, P.: Irreversible climate change due to carbon dioxide emissions, P. Natl. Acad. Sci. USA, 106, 1704-1709, 2009.
Thompson, S. L. and Barron, E. J.: Comparison of cretaceous and present earth albedos: implications for the causes of paleoclimates, J. Geol., 89, 143-167, 1981.

Tie, X. X., Madronich, S., Walters, S., Edwards, D. P., Ginoux, P., Mahowald, N., Zhang, R. Y., Lou, C., and Brasseur, G.: Assessment of the global impact of aerosols on tropospheric oxidants, J. Geophys. Res., 110, D03204, doi:10.1029/2004JD005359, 2005.

Vavrus, S. J. and Waliser, D.: An improved parameterization for simulating Arctic cloud amount in the CCSM3 climate model, J. Climate, 21, 5673-5687, doi:10.1175/2008JCLI2299.1, 2008.

Velicogna, I.: Increasing rates of ice mass loss from the Greenland and AISs revealed by GRACE, Geophys. Res. Lett., 36, L19503, doi:10.1029/2009GL040222, 2009.

Wilson, D. S., Jamieson, S. S. R., Barrett, P. J., Leitchenkov, G., Gohl, K., and Larter, R. D.: Antarctic topography at the Eoceneoligocene boundary, Palaeogeogr. Palaeocl., 335-336, 24-34, doi:10.1016/j.palaeo.2011.05.028, 2011.

Zachos, J. C., Pagani, M., Sloan, L., Thomas, E., and Billups, K.: Trends, rhythms, and aberrations in global climate $65 \mathrm{Ma}$ to present, Science, 292, 686-693, 2001.

Zanazzi, A., Kohn, M. J., MacFadden, B. J., Terry, D. O. J.: Large temperature drop across the Eocene-oligocene transition in Central North America, Nature, 445, 639-642, doi:10.1038/nature05551, 2007.

Zhang, G. and McFarlane, N.: Role of convective-scale momentum transport in climate simulation, J. Geophys. Res., 100, 14171426, doi:10.1029/94JD02519, 1995. 